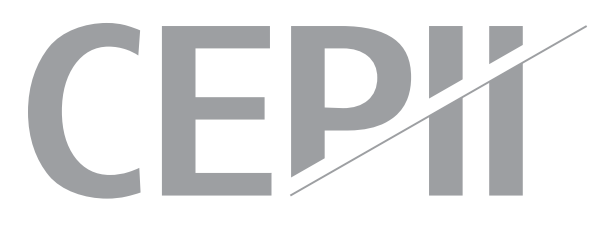

\title{
Are Global Value Chains Receding? The Jury Is Still Out. Key Findings from the Analysis of Deflated World Trade in Parts and Components
}

\author{
Guillaume Gaulier, Aude Sztulman \& Deniz Ünal
}

\section{Highlights}

- Over the period 2000-2016, the share of intermediate goods in world trade in nominal terms is fairly well correlated to various Global Value Chain (GVC) indicators based on international input-output matrices: a moderate expansion of international fragmentation followed by a decline from 2011 onwards.

- However, taking into account price effects (using an original deflator by production stages based on very detailed and harmonised bilateral trade unit-values), our results show a different evolution: the intermediate trade share in volume is growing at a subdued rate between 2000 and 2016.

- Focusing on the manufacture of Parts and Components (P\&C), which corresponds to activities more embedded in GVCs than other intermediate goods, that is, semi-finished products, the same pattern emerges, namely a slight increase in the share of $\mathrm{P} \& \mathrm{C}$ in manufacturing world trade in volume. Furthermore, after controlling for the global business cycle, there is a modest but steady rise, with no sign of a downturn after the Great Recession.

- GVCs are particularly well-developed for electronics, the share of this sector in P\&C trade being the highest and remaining stable over the period. However, subsectors exhibit contrasting development: P\&C trade related to office machinery and computers receded while trade in telecommunications equipment, the flagship IT revolution industry, thrived.

- Counts of clients or suppliers by stages of production indicate a higher and growing geographical diversity for P\&C. 


\section{Abstract}

In this article, we examine the dynamics of Global Value Chains (GVCs) since the 2000s. Did it show a marked expansion up to the Great Recession and did GVCs begin a downturn in the 2010s? To better understand the evolution of GVCs at the world level, we use very detailed trade data for 2000 to 2016, which distinguishes different production stages along the GVC. In particular, among intermediate goods, we focus on Parts and Components (P\&C) rather than semi-finished products since the manufacture of P\&C corresponds to activities more embedded in GVCs. We control, also, for the global business cycle and price effects using an original production stages deflator based on detailed bilateral trade unit-values. This new GVC indicator shows moderate growth over the study period with no trend reversal. In the electronics sector, where GVCs are particularly well-developed, we observe contrasting effects: the share in P\&C trade for office machinery and computers has decreased, while it has increased in the case of telecommunications equipment, the flagship IT revolution industry. Also, counts of clients or suppliers by stages of production indicate higher and growing geographical diversity for P\&C.

\section{Keywords}

Global Value Chains, Parts and Components - P\&C, Trade in Volume; Electronics.

\section{JEL}

F14, F15, L60.

\section{Working Paper}

\section{CEPI}

CEPII (Centre d'Etudes Prospectives et d'Informations Internationales) is a French institute dedicated to producing independent, policyoriented economic research helpful to understand the international economic environment and challenges in the areas of trade policy, competitiveness, macroeconomics, international finance and growth.
CEPII Working Paper

Contributing to research in international economics

C C CEPII, PARIS, 2019

All rights reserved. Opinions expressed in this publication are those of the author(s) alone.

$\begin{array}{ll}\text { Editorial Director: } & \text { CEPII } \\ \text { Sébastien Jean } & \text { 20, avenue de Ségur } \\ & \text { TSA 10726 } \\ \text { Production: } & 75334 \text { Paris Cedex } 07 \\ \text { Laure Boivin } & +33153685500 \\ & \text { www.cepii.fr } \\ \text { No ISSN: } 1293-2574 & \text { Press contact: presse@ }\end{array}$




\title{
Are global value chains receding? The jury is still out. Key findings from the analysis of deflated world trade in parts and components
}

\author{
Guillaume Gaulier, Aude Sztulman, Deniz Ünal
}

The same product is crafted or can be crafted in a certain way from one people, in a different way from a second people, in a yet different way from a third people and so on. It crosses five or six borders and is processed five or six times before it reaches the hands of a merchant who will sell it nearby or faraway, in his own city or in the other hemisphere. Here is muslin that was perhaps woven in Saxony with Manchester yarn obtained from a mixture of cottons harvested in Surate in India, in Mobile in the United States and in Egypt: it is embroidered in Nancy to be sold in Philadelphia or in Canton or in Batavia[Java] after having passed through a warehouse in New York or in HonKong[sic] or in Singapore.

M. Chevalier, exposition universelle de Londres en 1851 (p. 498) quoted from Todd D. (2017), " 1860 L'autre pays du libre-échange ", in L'Histoire mondiale de la France, directed by P. Boucheron, éditions du Seuil, p. 497-501.1

As Michel Chevalier's statement shows, the world-wide organisation of production is well established. However, although not a new phenomenon, international production sharing has increased since the 1980s. The 1990s and early 2000s are often considered periods of unprecedented development of Global Value Chains (GVCs) and the expansion of GVCs has contributed to the boom in world trade. The crucial role of GVCs in the globalization process is reflected in the growing academic attention afforded to them. ${ }^{2}$ Richard Baldwin (2016, pp.5-6) underlines that:

Globalization accelerated again from around 1990, when the ICT revolution radically lowered the cost of moving ideas. This launched globalization's next phase-call it the "second unbundling" since it involves the international separation of factories. [...] As a consequence, the second unbundling - sometimes called the "global value chain revolution"- redrew the international boundaries of knowledge. The contours of industrial competitiveness are now increasingly defined by the outlines of international production networks rather than the boundaries of nations.

\footnotetext{
*Guillaume Gaulier is an economist at the Banque de France, Associate Professor at the Université Paris 1 Panthéon-Sorbonne and research associate at CEPII (Guillaume.GAULIER@banque-france.fr), Aude Sztulman is Associate Professor at DIAL, LEDa, IRD, Université Paris-Dauphine, Université PSL, (aude.sztulman@dauphine.psl.eu), Deniz Ünal is an economist at CEPII (deniz.unal@cepii.fr), editor-in-chief of Panorama du CEPII and coordinator of the CEPII Country Profiles Visualdata .

We thank Guillaume Daudin, Lionel Fontagné, Sébastien Jean, Pierre Sicsic, Vincent Vicard and participants in Banque de France (25 June, 2018) and CEPII (12 July, 2018) seminars for helpful comments. We are grateful, also, to Michele Mancini and Marcel Timmer for making their data available to us.

The views expressed in this paper are those of the authors and do not represent those of the Banque de France or the Eurosystem. The usual disclaimers apply.

${ }^{1}$ Our translation.

2 A World Trade Report (WTO, 2014) indicates that a Google Scholar search on the phrase "global value chains" reveals dramatic growth in the scholarly literature between 1980 and 2013. Appendix 1 Figure A.1 shows the results of the same Google Scholar search for the period 1980-2017 and reveals a similar academic interest in the issue.
} 
However, questions are being raised about the possibility of a slowdown in the international production fragmentation process and its effect on global trade growth during the 2011-2016 period. ${ }^{3}$

Several empirical studies have tried to identify the main factors underlying world trade growth evolutions, the rise in world trade during the 1990s and 2000s, and its recent slowdown. ${ }^{4}$ Among the many determinants identified, are cyclical and structural factors, and the international fragmentation of production in GVCs is considered to have played a key role in world trade dynamics since the $1990 \mathrm{~s} .{ }^{5}$ In relation to the recent trade slowdown, the repositioning of the Chinese economy in its domestic market ${ }^{6}$ and declining GVC participation ${ }^{7}$ are regarded as important contributors. ${ }^{8}$ However, there are several other drivers including a weak economic environment with low levels of investment and scant final demand in the wake of the Great Recession and the ensuing euro area crisis, ${ }^{9}$ deceleration of the trade liberalization process and increased non-tariff protection measures, smaller transportation cost reductions and higher relative demand for non-tradable goods, limited trade finance, and so on.

We are especially interested, in this article, in the dynamics of GVCs since 2000. Did they exhibit a marked expansion up to the time of the Great Recession and are GVCs experiencing a downturn in the 2010s? To better understand the evolution of GVCs at the world level, we use disaggregated trade data, which distinguish different production stages along the global value chain, in particular Parts and Components (P\&C) and semi-finished products. Furthermore, we take account of price effects through the construction of an original production stages deflator (based on disaggregated bilateral trade unit-values). To better grasp GVC dynamics, global business cycles are controlled for and the evolution of GVCs is examined at the sectoral level. We then adopt a different standpoint by using data on number of clients by exporter, and number of suppliers by importer (by country and product) to provide a set of quantitative information on the geographical diversity along GVCs, that is, on the extensive margins.

We show that the share of intermediate goods in world trade, in nominal terms, is fairly well correlated to various GVC indicators, based on International Input-Output (IIO) matrices. A moderate rise in the 2000s is followed by a trend reversal after 2011. Intermediate trade shares - computed on gross trade flows only - are much less data demanding, provide information for a longer time span and can be readily updated, while IIO based measures, inter alia, require country level data on value added flows and are published irregularly. Another advantage of using this world level GVC indicator is the relative ease of obtaining volume calculations. When accounting for price effects, the intermediate trade share shows a different evolution: it is growing at a low rate between 2000 and 2016. Similarly, focusing on the manufacture of P\&C,

\footnotetext{
3 The period analysed in this paper is 2000-2016. The slowdown in world trade growth occurred between 2011 and 2016. After the Great Recession, world trade growth did not return to its pre-crisis level. The latest statistics show a slight increase of $2.5 \%$ in 2016 (and a strong rebound of 5.2\% in 2017). Projections for 2018 and 2019 are $4.2 \%$ and $4 \%$ compared to a growth rate of $3.7 \%$ for world output for these years (IMF, 2018).

${ }^{4}$ Concerning the global trade slowdown and its determinants, see, e.g., the research contributions in the ebook edited by Hoekman (2015).

${ }^{5}$ See Johnson and Noguera (2012, 2017), Haugh et al. (2016) and Timmer et al. (2016).

${ }^{6}$ See Lemoine and Ünal (2017), Gaulier et al. (2016), Gaulier et al. (2015).

${ }^{7}$ See Crozet et al. (2015).

${ }^{8}$ Before the Great Recession, China was central to the expansion of GVCs, as companies (particularly foreign owned) demanded large quantities of inputs (P\&C - parts and components, etc) destined for the production of many consumer goods for export.
}

${ }^{9}$ See, e.g., IMF (2016, Ch. 2) and Boz et al. (2015), on the role of investment decline and import intensity in capital goods and Ollivaud and Schwellnus (2015) on the role of weaker demand in the euro area. 
which includes industries typical of the "second unbundling (Baldwin, 2016), and corresponds to activities embedded more deeply in GVCs compared to semi-finished products, we observe a slight increase of the P\&C's share in manufacturing world trade in volume. Further, if we control for the global business cycle, we find a modest rise and no sign of a downturn after the 2008-09 global crisis. Also, these GVC evolutions are not the result of a sectoral composition effect and, according to our indicator, there is no indication of a recent GVC decline for the main branch groups. Finally, counts of clients or suppliers by production stages also indicate higher and growing geographical diversity for P\&C.

\section{GVCs: concepts and measurement issues}

Both theoretical and empirical studies show that the international segmentation of production processes is a major underlying factor in the trade flows between countries. Production steps have become fragmented internationally, as firms located in different countries take part in the production of a good (or a service), in different stages of the value-added chain (Baldwin, 2016). Countries specialize in the supply of specific tasks rather than production of the entire final good and it is this vertical division of labour that is at the origin of countries' comparative advantage at different stages of the production process leading to a "trade in tasks" (Grossman and Rossi-Hansberg, 2008).

Therefore, a GVC involves combining domestic and imported inputs into the production processes to manufacture goods and services that are exported for another stage of production or incorporated into the final good, which is sold domestically ${ }^{10}$ or exported. GVC expansion can be the result of various factors. The international segmentation of production occurs in sectors where the production process can be broken down into technologically separate and independent operations, providing intermediate inputs to be assembled into the final product (Lassudrie-Duchêne, 1985). Technological progress can, but may not necessarily, contribute to the evolution of GVCs. Following Bloom et al. (2009), Baldwin (2016) distinguishes the effects of coordination ${ }^{11}$ and information technologies. While the former favours the international fragmentation of production, the latter - for example, automation - could enable more onshoring. ${ }^{12}$ Moreover, trade corresponding to an international segmentation of production process is enhanced by the lowering of transport and communication costs. Multinational firm strategies inevitably play a key role as companies decide to develop sourcing policies relying on foreign and sometimes distant suppliers. Offshoring - either through inhouse sourcing (within a multinational firm) or outsourcing (to independent contractors) - has increased imports of intermediate inputs and, as a result, the development of GVCs is at the heart of massive (intra- and inter-firm) trade flows of intermediate goods (and services), in particular of P\&C (Fontagné, 1991).

GVCs are an international network of the stages of production and capturing their evolutions statistically raises several problems since it requires the tracking of value added through supply and use linkages, both between sectors and across borders. Most studies of "vertical specialization" (Hummels et al., 2001) draw on global input-output matrices, which are difficult to obtain and are published only for limited and recent periods. This limits the availability of up-

\footnotetext{
${ }^{10}$ Depending upon how a GVC is defined, the import of intermediate goods to produce a final good that is consumed domestically is included or not. See below.

${ }^{11}$ Coordination technologies are technologies that facilitate any form of transmission.

12 "Better CT (coordination technologies) favor fractionalization by making it cheaper; better IT (information technologies) discourages fractionalization by making it less necessary" (Baldwin, 2016, pp. 200-201).
} 
to-date tables over time. ${ }^{13}$ Moreover, as Johnson (2017) points out, the construction of such matrices relies on numerous methodological assumptions: for example, in some studies, production destined for different foreign markets or the domestic market of a given industry, is assumed to contain the same proportion of foreign input from various industries. ${ }^{14}$ This assumption does not hold in the case, for example, of China's processing and ordinary trade flows (Lemoine and Ünal, 2017).

Another and much simpler way to study the international fragmentation of production at the world level is to examine the evolution of the share of intermediate goods in global trade. As explained above, a consequence of the international segmentation of production processes is a growing share of intermediate products in world trade, in particular P\&C. Trade flow statistics by production stages, are relatively easy to compute since the data are directly available with few constraints on their temporal, sectoral or geographical dimensions.

Admittedly, trade in intermediate goods does not correspond absolutely to all cross border production-sharing activities included in GVCs and is not fully integrated in GVCs. For example, at country level, GVC participation indexes usually include both the export's foreign value added as a share of the country's gross exports, and the domestic content in the country's exports that then is exported by its trading partners (i.e., backward and forward engagement in GVCs). According to this definition, not all intermediate goods trade flows are embedded in GVCs and, especially, those used for the production of a good destined for the domestic market. ${ }^{15}$ Furthermore, some GVC production stages, such as final assembly activities, are not included in intermediate goods trade.

To measure country level GVC participation or bilateral offshoring, ${ }^{16}$ the availability of IIO tables is a positive development since it provides information on the origins of all value added flows imported by a given country. Johnson $(2017$, p. 6) highlights that IIO matrices allow both the possibility of some domestic content in imported inputs and the "multilateral nature of GVCs": bilateral foreign content can indeed "travel indirect routes (via third countries) from its source

\footnotetext{
13 The joint OECD-WTO Trade in Value-Added (TiVA) database provides indicators for the years 1995 to 2015 with successive editions based on different Systems of National Accounts and industrial classifications (latest edition 2018) while the World Input-Output Database (WIOD) covers the period 2000-2014 (published in 2016).
}

${ }^{14}$ More precisely, Johnson (2017, p. 19) discusses two types of problems in the construction of global input-output tables: "One problem is that the 'use table' in the input-output accounts - which tracks how commodities are used as inputs by individual industries - does not distinguish between patterns of input use for domestically produced versus imported goods/services. This implies that one must use assumptions (or data imputation techniques) to decompose input use across sources. Most commonly, imported input use tables are constructed using "proportionality" (alternatively, "import comparability") assumptions, under which imported inputs are allocated across sectors in the same proportion as domestic goods. Further, the proportionality assumption is naturally applied to total imports, so inputs from all bilateral trade partners are treated in the same way. In plain language, the input-output segment of the national accounts do not directly tell us how much imported steel is used in US car production, nor whether imported steel from Canada versus Japan are used in the same way. A second problem is that imported inputs are assumed to be used with equal intensity in industry-level production for domestic and export markets. When imported input intensity differs across firms within an industry, then using the average input intensity reported in input-output tables to represent production techniques may lead to large biases in measurement of the value added content of trade and other GVC metrics".

${ }^{15}$ WTO (2014, p. 80) states that inter-country input-output indicators often make "the assumption that the production network is composed of at least three different stages or steps performed sequentially in different countries". The import of intermediate goods to produce a final good that is consumed domestically or "direct absorption" is excluded by Borin and Mancini (2017), e.g., in their GVC participation index: for these authors a GVC corresponds to at least two international shipments.

${ }^{16}$ To illustrate the measurement difficulties related to bilateral offshoring, Johnson $(2017$, p. 6) takes the example of Mexico and the US: "consider trying to measure Mexican content in US-produced cars, and suppose that the US uses imported engines from Mexico. [...] First, the US might export inputs (e.g., spark plugs) to Mexico that are embodied in Mexican engines. Second, Mexican engines might include value-added content from third countries (e.g., steel from China). These higher-order input linkages would lead the conventional import share measure to overstate how much Mexican value added is embodied in US cars". 
to where it is ultimately used in production". However, at the global level, knowledge about all value-added trade flows between countries is not required and the share of intermediate goods in world trade is a valid proxy for GVC dynamics. ${ }^{17}$

The differences between an IIO based measure of GVCs and the share of intermediate goods in world trade are depicted in the simplified example of a three-country "global" value chain (see Figure 1).

\section{Figure 1 \\ Three country "global" value chain example}

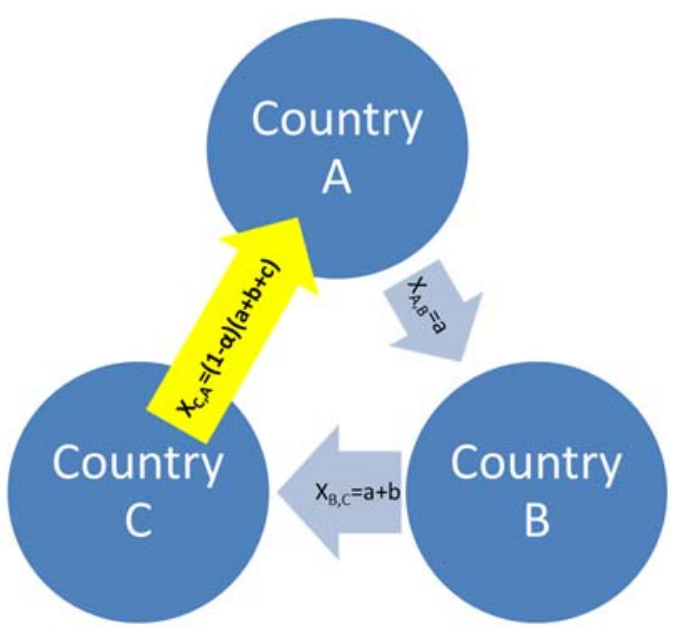

In our schematic GVC, Country $A$ exports to Country $B$ an intermediate good with a value added $a$, and Country $B$ re-exports this intermediate good to Country $C$, adding a value added $b$. Country $C$ then incorporates the imported inputs in a final good after adding a value added $c$; a share $\alpha$ of the gross output of the final good is consumed domestically while a share $(1-\alpha)$ is exported to Country $A .^{18}$

In this schematic GVC, world trade (WT), intermediate goods world trade (IGWT) and world trade in value added (VAWT) correspond respectively to:

$$
\begin{aligned}
& W T=X_{A, B}+X_{B, C}+X_{C, A}=a(3-\alpha)+b(2-\alpha)+c(1-\alpha) \\
& I G W T=X_{A, B}+X_{B, C}=2 a+b \\
& V A W T=a+b+c(1-\alpha)
\end{aligned}
$$

\footnotetext{
${ }_{17}$ Nevertheless, even at country level, intermediate goods trade data capture a high share of a country's GVC activities. E.g., according to an OECD (2013) report, for most economies, on average, around one-third of intermediate imports end up in exports. Of course, the differences are large between both industries and countries and are linked to the size of the country. In Hungary, nearly two-thirds of all intermediate imports are exported compared to $22 \%$ in Japan and $17 \%$ in the US. In the electronics sectors in China, South Korea and Mexico, threequarters of intermediate imports are exported and in Hungary the figure is $85 \%$ (OECD, 2013).

${ }^{18}$ The share (1- $\alpha$ ) could have been exported to Country $B$; in the interests of keeping the figure simple and since it does not change our indicator values because at the global level we only consider the total sum, we do not consider this possibility here. Furthermore, again for simplicity, Country $B$ does not use a share of $X_{B, C}$ domestically. Finally, it would have been possible to add values for trade flows not embedded in GVCs.
} 
A frequently used IIO-based measure of GVCs (Johnson and Noguera, 2017) is the ratio of gross to value added world exports, i.e. WTNAWT. ${ }^{19}$

$$
G V C_{-} I I O=\frac{\mathrm{a}(3-\alpha)+\mathrm{b}(2-\alpha)+\mathrm{c}(1-\alpha)}{\mathrm{a}+\mathrm{b}+(1-\alpha) \mathrm{c}}
$$

To compute this indicator requires knowledge of $a, b$ and $c$ which is not directly observable for all countries and products and, therefore, poses a number of measurement difficulties at the world level, especially for GVCs that involve many countries (see above).

Hence, here, we consider the more easily measured proxy of the share of intermediate goods in world trade:

$$
G V C_{I G}=\frac{2 \mathrm{a}+\mathrm{b}}{\mathrm{a}(3-\alpha)+\mathrm{b}(2-\alpha)+\mathrm{c}(1-\alpha)}=\frac{I G W T}{W T}
$$

Such a GVC indicator (computed only from gross trade flows at world level) is directly observed and, thus, requires no information on the value added flows, a, b and c. ${ }^{20}$ This measure is both easy to compute and interpret and allows GVCs to be tracked at the global level in a simple and transparent manner.

\section{GVCs inter-country input output indicators and intermediate goods trade share}

Studies using IIO-based measures show that GVCs expanded in the 2000s before either plateauing or decreasing in more recent years (Aslam et al., 2017; Timmer et al., 2016; Haugh et al., 2016, Los et al., 2015). For instance, Timmer and co-authors (2016, p. 30) created an indicator of the Global Import Intensity (GII) of production which "measures the imports needed in any stage of production". This indicator is based on world input-output tables from the World Input-Output Database (WIOD) for 836 final goods ${ }^{21}$ over the period 2000-2014. To better identify GVC dynamics, the authors regress Glls on a set of annual dummy variables and country-industry pair dummies.

Figure 2.A shows the shift in the pattern of international production networks, with a period of expansion of the international fragmentation process after 2002 followed by a relative decline from 2011. Borin and Mancini $(2015,2017)$ use a different type of inter-country input-output indicator, but find a similar GVC evolution. Their index of GVC participation measures "production processes that require at least two international shipments of goods (including both intermediate inputs and final products)" (Borin and Mancini, 2017, p. 23);22 in addition, it is

\footnotetext{
19 Timmer et al. (2016) point out that this indicator of production fragmentation tracks forward as opposed to backward linkages. In our view, this distinction is relevant mainly at the country or bilateral level.

${ }^{20} \mathrm{Here}$, a rise in the share $\alpha$ of imported inputs that are not re-exported has a positive impact on GVC_IG. Conversely, it has a negative impact on $G V C_{-} I I O$. It is questionable whether this share of imported inputs used for the production of a good sold domestically should have an influence on an indicator measuring GVCs intensity at the world level, and which direction is appropriate.

21836 GVCs corresponding to 19 manufacturing industries for 44 final destination countries.

22 "The measure is estimated using bilateral trade data based on the World Input-Output Database (WIOD). It excludes the fraction of domestic value added that is exported only once and directly absorbed by the destination country. The remaining part of exports is considered part of global value chains processes and is divided by total trade of a country or region to obtain the GVC participation index. The index is adjusted for commodity price effects by setting to zero valued added in energy sectors." (IRC Trade Task Force, 2016, p. 25).
} 
adjusted to take account of changes to the composition of demand. ${ }^{23}$ Again, we see GVCs expanding during the 2000s and declining from 2011 (see Figure 2.B). Interestingly, as recent European Central Bank (ECB), OECD and World Trade Organization (WTO) research ${ }^{24}$ claims, evolution of the trade in intermediate goods and GVCs at the global level appears to be similar: Figure 2.B shows that the share of GVCs in total trade (as measured by Borin and Mancini, 2017), and the share of intermediate trade in nominal terms, are strongly correlated and point to initially increased GVC intensity followed by a fall after 2011. Over the period, and at world level, intermediate trade shares seem to carry the same information on GVCs as IIO based GVC measures.

Intermediate trade shares as opposed to IIO based GVC measures could be an alternative for analysis of GVC dynamics at world level.

However, such a measure of GVCs has some limitations. In certain cases, as Hummels et al. (2001) point out, the product classification used to distinguish production stages - namely the United Nations Broad Economic Categories (BEC) - can be misleading: for example, a car embedded in a GVC (i.e., for reexport after some transformation) may be classified as a consumption good; conversely, a tyre, classified as an intermediate good, can be sold directly to a consumer. However, since the BEC provide a highly disaggregated classification, this categorisation problem should be limited in our case: misclassifications are likely to cancel each other out when the totality of world trade flows is considered. Moreover, this problem is not specific to the share of intermediate goods in world trade since the BEC are used, also, to construct data on value-added flows (e.g., WIOD). Another limitation of intermediate trade shares is the exclusive coverage of GVCs in goods rather than services production (although services incorporated in manufactured goods are included). ${ }^{25}$

\footnotetext{
${ }^{23}$ Borin and Mancini (2017, p. 25) adjust their indicators of GVC-related trade "by 'neutralizing' the changes in demand composition and using constant prices input-output tables available in the WIOD database". See fn. 27 for a detailed description of their procedure.

24 IRC Trade Task Force (2016), Haugh et al. (2016) and WTO (2014).

25 Therefore, it is better adapted to the "second unbundling" rather than the ongoing "third unbundling" taking place through remote services (Baldwin, 2016).
} 
Figure 2

Measuring GVCs evolutions

Inter country input output indicators and intermediate goods trade share

A. Trend in international fragmentation of goods production Global import intensity

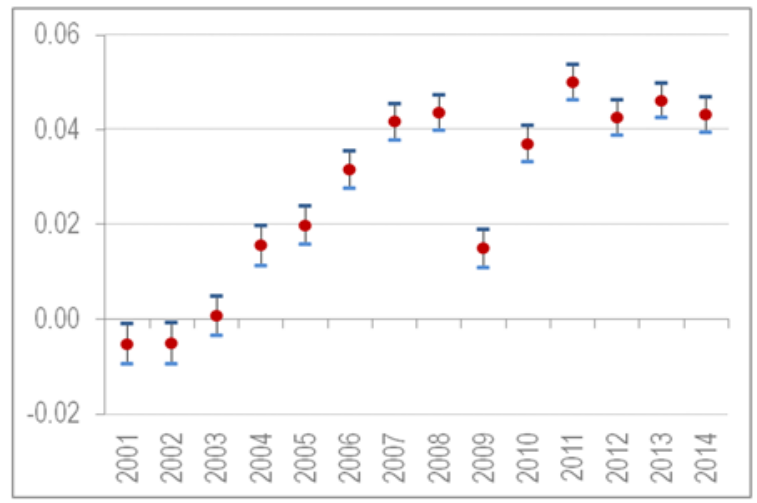

Notes: Global Import Intensities (GII) regressions of GVCs on dummies for final country-industry and years. The figure presents estimated coefficients and 95\% confidence intervals for the year dummies, relative to 2000 . The observations $(11,889)$ are weighted by final output excluding trade in products from the mining industry (WIOD Sector 4) and petroleum refining (WIOD sector 10).

Source: data from Timmer et al. (2016) provided by Marcel Timmer.

B. GVC share of total trade and share of intermediate goods in total goods imports (\%)

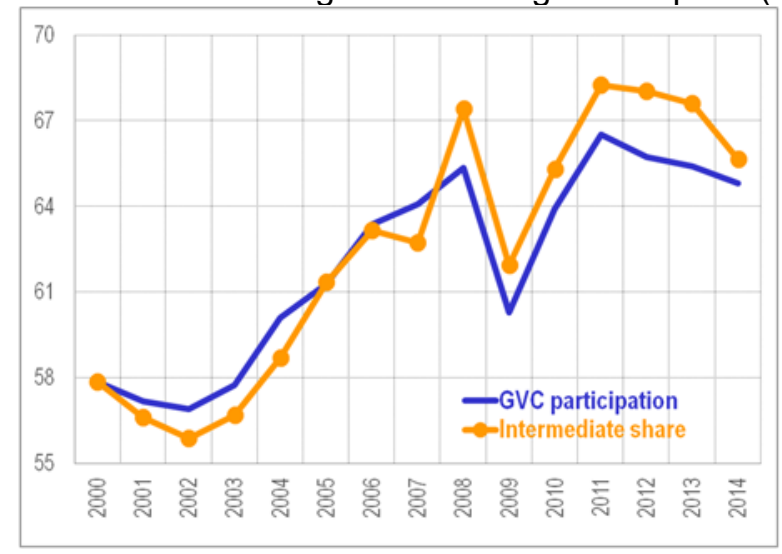

Notes: The GVC participation index is explained in the text. Both measures exclude energy-related trade. GVC participation is rebased to be equal to the intermediate trade share in 2000 and its evolution is calculated based on its 2000-2014 growth index.

Source: data from Borin and Mancini (2017) provided by the publication's authors.

Overall, the share of intermediate goods in global trade in nominal terms is fairly well correlated to various GVC indicators based on IIO matrices. It is much less data demanding and provides information for both recent years and a longer time span, unlike the irregularly published IIO based measures. This world level GVC indicator can also be updated regularly. As shown below, another advantage of this measure is the relative ease of obtaining deflators at the detailed product level and, therefore, volume calculations. 


\section{Mapping GVCs through intermediate goods trade shares: parts and components versus semi-finished products}

In this study, we use detailed trade flows and trade unit values drawn from the World Trade Flows Characterization (WTFC) dataset. ${ }^{26}$ This CEPII dataset provides harmonised unit values, categorisation by type of trade (one- and two-way trade) and price-quality ranges of bilateral trade flows for more than 230 countries and 5,000 products (HS6) over the period 2000-2016. It is constructed from two other CEPII databases, TUV (Trade Unit Values) and $\mathrm{BACl}$ (Base Analytique du Commerce International). ${ }^{27}$ As Emlinger and Piton (2014) suggest, WFTC data have two main advantages: improving data quality and increasing data availability. The TUV dataset offers indeed more reliable and consistent unit values than the UN COMTRADE database. Furthermore, WTFC is a harmonised version of TUV and the harmonisation procedure increases the quality and the number of unit values (see Appendix 2 for more details).

Our study distinguishes different production stages along the GVC. Production stages are classified according to their use. Upstream of the production process are primary goods used either directly or after processing. Intermediate goods act as inputs to the production process and correspond to any manufactured goods that are reintroduced into the production cycle and disappear (are transformed) during that cycle. Semi-finished products are subjected to further processing while P\&C - already 'finished' products - are intended for assembly. Downstream of the value chain are capital and consumer goods, which are for final use respectively by producers and consumers. For our analysis, we consider only the manufacturing sector excluding production of coke, refined petroleum products and nuclear fuel. ${ }^{28}$

Using detailed trade data for the period 2000-2016 from CEPII's WFTC database, we compute trade shares by production stages ${ }^{29}$ with the aim, in particular, to distinguish semi-finished products from P\&C within intermediate goods. Separate analysis of these two stages among intermediate products might provide additional insights into GVC dynamics since the manufacture of P\&C (which includes electronics, automotive industry, etc.) corresponds to activities more deeply embedded in GVCs than semi-finished goods production (which includes chemicals, basic metals, etc.). Yeats (1998), for example, using the trade share of P\&C, shows that global production sharing increased over the 1978-1995 period. Following Baldwin (2016), we go a step further and consider the phenomenon of two-way trade ${ }^{30}$ as indicative of production fragmentation. In Figure 3 high levels of two-way trade flows for intermediate products, especially for $\mathrm{P} \& \mathrm{C}^{31}$, relative to final goods, indicate the international segmentation of production.

\footnotetext{
${ }^{26}$ The Appendix 2 provides a detailed description of the WFTC dataset.

${ }^{27}$ Detailed presentations of TUV and $\mathrm{BACl}$ are set out respectively in Berthou and Emlinger (2011) and Gaulier and Zignago (2010).

${ }^{28}$ Manufacturing sector groups ISIC 2 digit branches from 15 to 36 (except 23 - coke, refined petroleum and nuclear products) and excluding commodities and not elsewhere specified products.
}

${ }^{29}$ See Appendix 3 for the classification by stages of production, branch groups and branches as well as a breakdown of world trade in all products (2000-2016 average, \% total).

${ }^{30}$ Following CEPII's methodology (Emlinger et al., 2016; Fontagné and Freudenberg, 1997), trade at the countrypartner-product-year level is considered two-way or intra-industry if the value of the minority flow (the smallest value between the export and import flows) represents at least $10 \%$ of the majority flow: $\frac{\operatorname{Min}\left(X_{i j}^{k}, M_{i j}^{k}\right)}{\operatorname{Max}\left(X_{i j}^{k}, M_{i j}^{k}\right)}>10 \%$ with $X_{i j}^{k}$ and $M_{i j}^{k}$ corresponding respectively to exports and imports in value from country $i$ to country $j$ for a product $k$ (6-digit level of the Harmonized System classification). If the ratio is below this $10 \%$ threshold, the flow is considered to be one-way.

${ }^{31} \mathrm{P} \& \mathrm{C}$ are more differentiated horizontally and vertically than semi-finished products. 
Figure 3

Intermediate goods and two-way trade, 2000-2016 average, manufacturing trade in value

\section{A. Share of two-way trade (in $\%$ of production stage)}

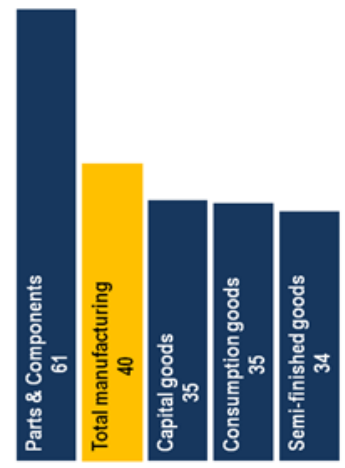

B. Two-way trade breakdown by production stages (\%)

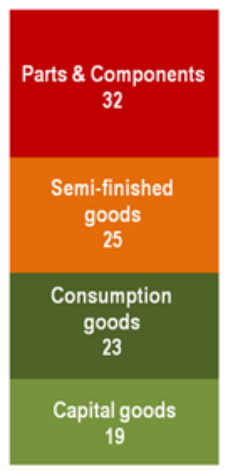

C. Two-way trade in semi-finished goods breakdown by industry groups (\%)

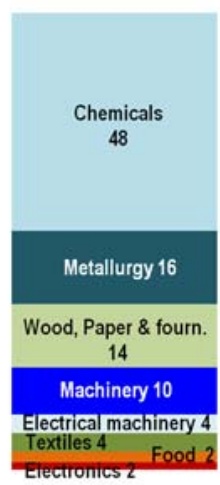

D. Two-way trade in parts \& components breakdown by industry groups (\%)

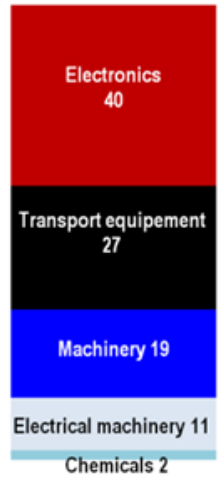

Notes: Intermediate goods include semi-finished products and P\&C. One-way and two-way trade are calculated according to the CEPII's methodology (Emlinger et al., 2016; Fontagné and Freudenberg, 1997). Production stages are classified according to BEC classification.

Source: Authors' calculations from CEPII's WTFC database.

On average, in the 2000-2016 period, $\mathrm{P} \& \mathrm{C}$ recorded the highest share $(61 \%)$ of two-way trade; semi-finished goods achieved $34 \%$, lower than the share of capital and consumption goods. The share of P\&C in total two-way trade was $32 \%$, compared to $25 \%$ for semi-finished goods. Among industry groups, two-way trade in P\&C occurs mainly in electronics, transport equipment (automotive sector) and machinery. These industries are the sectors typical of the "second unbundling" (Baldwin, 2016). In the case of semi-finished products, most two-way trade flows are related to chemicals (48\%). Thus, to study GVC dynamics requires account to be taken of P\&Cs. Since GVCs (and two way trade) tend to be organised on a regional basis (Fontagné and Santoni, 2018), Appendix 4 provides a regional breakdown of P\&C trade $^{32}$ and highlights the central role of "Factory Asia" in the expansion of GVCs.

The results of our calculations of intermediate trade shares in manufacturing, based on detailed trade data for the period 2000-2016, are the same as those derived from IIO based measures; a moderate rise in the 2000s then a trend reversal since 2011 (see Figure 4.A). Note that growth between 2002 and 2011 (excluding the recession years 2009 and 2010) was limited and reached only $2.3 \% .{ }^{33} \mathrm{~A}$ breakdown of traded goods by production stages shows that trends depend strongly on the type of products considered (see Figure 4.B). Changes in the share of intermediate trade are due mainly to semi-finished products with the share of $P \& C$ remaining stable or declining slightly since 2000 .

\footnotetext{
32 However, Los et al. (2015) point out that regional fragmentation has increased less than global fragmentation.

33 This $4.5 \%$ rise (equivalent to $52.9 / 50.6-1$ ) is of a similar magnitude to the level in Timmer et al. (2016) (5\%) using their GVC indicator (see Figure 2.A).
} 
Figure 4

Share of intermediate goods in world trade for manufacturing (at current prices, in \%)

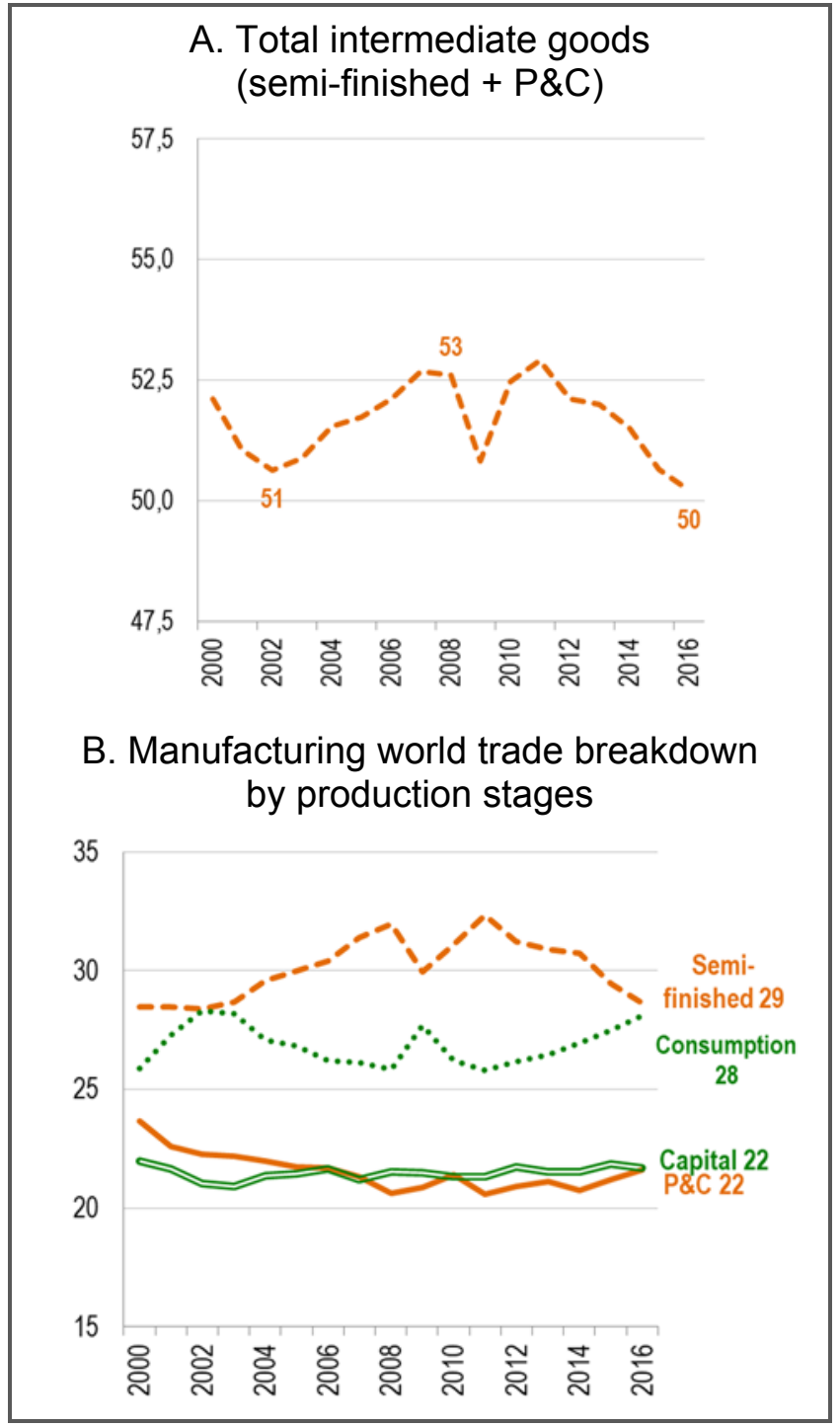

Note: See Appendix 5 for the share of production stages in total world trade at current prices.

Source: Authors' calculations from CEPII's WTFC database.

This result might be surprising since P\&C and more deeply embedded in GVC production activities than semi-finished products. It is possible that use of trade data at current prices provides misleading results. The evolution observed is due, in part, to price effects, which can have a much stronger impact on semi-finished product trade shares compared to P\&C.

\section{Controlling for price effects: trade flow volumes}

The findings for GVCs - derived from intermediate trade shares and IIO based measures could depend on the price treatment. However, gross trade and value added trade flows are not normally deflated. Taking account of price effects is important since the production of intermediate goods can involve a large share of commodities (especially oil) and, therefore, can be affected by variations in energy prices. For instance, as a result of composition effects, goods, such as semi-finished products, which undergo fewer transformations, may be more 
strongly affected by commodity price developments than P\&C, which represent a more downstream stage of production. Excluding the energy sector to control for such effects is not sufficient to remove the impact of commodity prices. ${ }^{34}$ Also, GVC expansion based on increased competition between production sites, exerts a downward pressure on prices that needs to be controlled for. ${ }^{35}$

To our knowledge, few empirical studies of GVC developments try to control for price movements or used deflated series (exceptions include Haugh et al., 2016; Borin and Mancini, 2017). To take account of price effects at the detailed international trade data level, we compute the deflators by production stages using bilateral trade unit-values (based on bilateral trade flows for around 5,000 products). Appendix 6 provides a comprehensive description of our methodology and the development of our trade unit value index by production stages. Unit values to measure prices might be considered questionable, ${ }^{36}$ but, as Redding and Weinstein (2017, pp. 22-23) emphasize:

... the coverage of sectors is much wider than in datasets that directly survey prices. As a result, many authors-including those working for statistical agencies-advocate for greater use of unit value data in the construction of import price indexes. Furthermore, existing research comparing aggregate import price indexes constructed using unit values and directly surveyed prices finds only small differences between them.

If we compare our deflator to similar indicators, we observe a fairly good match (see Appendix 6).

A large part of the 2002-2011 intermediate goods share increase in world trade at current values is linked to price effects. Indeed, calculated with deflated flows, this share remains fairly stable throughout the period (excluding 2009 and 2010) and shows no signs of a reversing trend in the more recent years (see Figure 5).

\footnotetext{
${ }^{34}$ See, e.g., IRC Trade Task Force (2016). As explained above, for this reason, in the manufacturing sector, we exclude branch 23 (in the ISIC Rev.3 classification) which corresponds to coke, refined petroleum products and nuclear fuel.

35 In Section 6 we show that P\&C trade involves a greater diversity of clients and suppliers than other stages of production, and that the gap increases over time.

36 Unit values can be subject of measurement error. However, at the world level, measurement errors are less severe since we use a unique deflator, with no country dimension, for each product. We also trim the top and bottom $5 \%$ of our indicators, which removes any large changes in elementary unit values.
} 
Figure 5

Share of intermediate goods

in world trade for manufacturing in volume

(at 2011 prices, in \%)

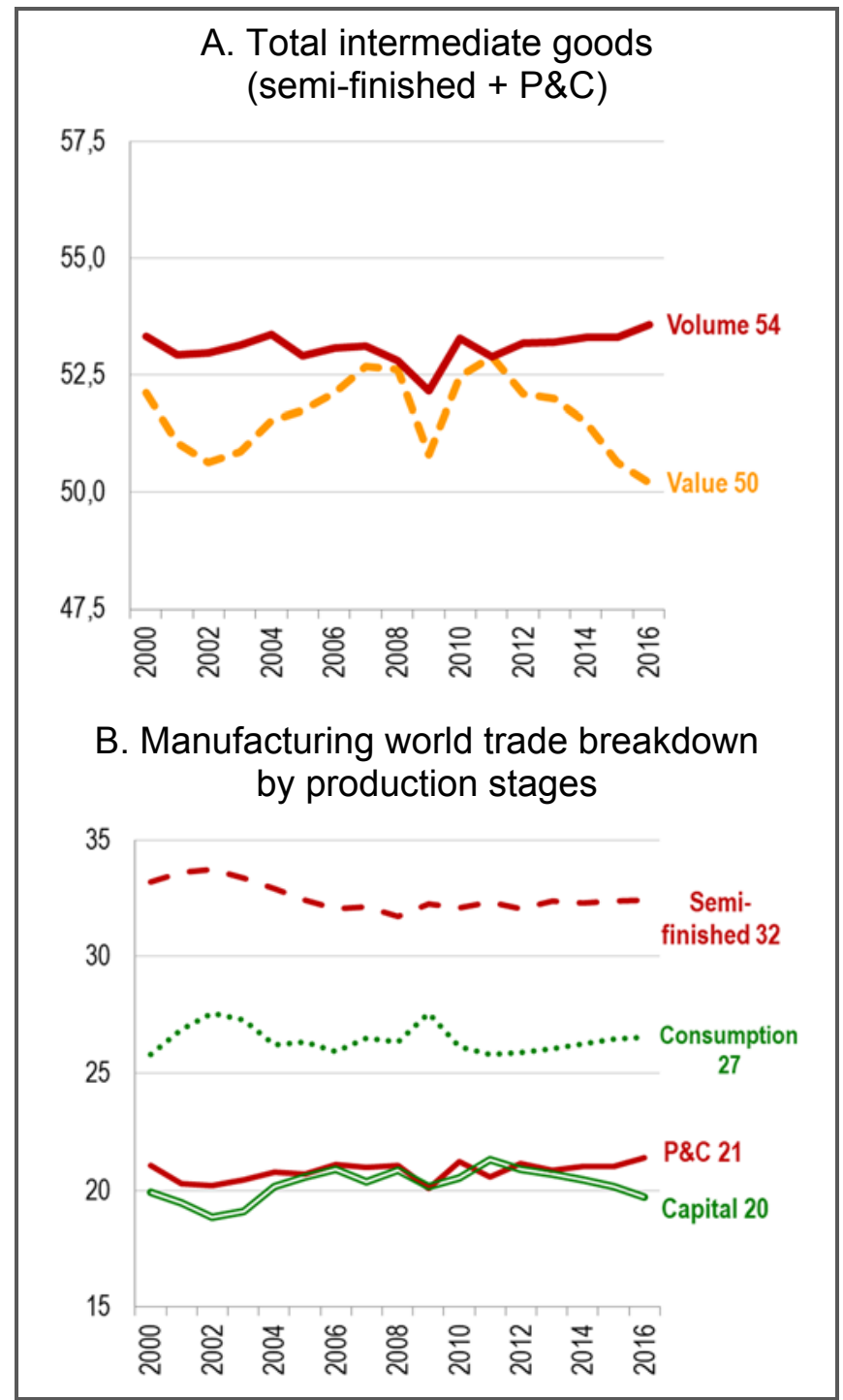

Note: See Appendix 5 for the share of production stages in total world trade in volume.

Source: Authors' calculations from CEPII's WTFC database.

A breakdown by production stages is also informative. Again, the results for semi-finished products and $\mathrm{P} \& \mathrm{C}$ are different. In the case of the former, much of the growth and subsequent fall in current values are linked to price effects. The share of semi-finished goods in volume decreased between $2002(33.7 \%)$ and $2006(32 \%)$ and has remained quite flat afterwards. In the case of P\&C, the share in volume slightly increased between $2002(20.2 \%)$ and 2016 $(21.4 \%)$. It is interesting that, for consumption goods, the share in volume is quite flat while, for capital goods, we observe a drop from $21.3 \%$ in 2011 to $19.7 \%$ in 2016 . This decrease in the manufacture of capital goods is consistent with reduced demand since the Great Recession.

In the following analysis of GVC dynamics, we focus on the share of P\&C in volume. 


\section{GVCs and business cycles}

Following Haugh et al. (2016), we control for cyclical movements. Our GVC indicator, based on P\&C, is likely to be affected by general economic conditions (see Figure 5.B). In their research, Haugh et al. (2016, p. 17) compute an indicator of "backward participation in GVCs", which is based on trade data and corresponds to the ratio of intermediate goods imports to final domestic demand, ${ }^{37}$ in nominal terms, for the 1991-2015 period. To exclude commodity prices and cyclical effects, the authors deflate their GVC indicator ${ }^{38}$ and regress the resulting indicator in volume on a measure of the output gap..$^{39}$ We adopt a similar approach: our GVC indicator - share in volume of P\&C in world trade for the manufacturing industries- is purged of business cycle effects by regressing it on a measure of the output gap and a trend (see Appendix 7 for the results of the estimation).

Both explanatory variables are statistically very significant. The trade share of $\mathrm{P} \& \mathrm{C}$ is higher when the world economy is booming with annual average growth of around $0.3 \%$ according to the trend coefficient. In Figure 6.A, recent GVC evolutions, taking account of price effects and business cycle, show no sign of a downturn after the 2008-09 global crisis.

\footnotetext{
${ }^{37}$ In contrast to trade shares, the denominator of their GVC index, i.e., final domestic demand, changes with the country's GDP (including demand for non-tradable goods). Therefore, an economic shock unrelated to GVCs (e.g., trade liberalisation measures at world level) is likely to influence this indicator. This does not apply to intermediate trade shares and trade shares by production stages, which are independent of any shocks that affect trade flows by production stages and total trade in a similar way. For this reason, trade shares might more accurately capture GVC dynamics.

38 The authors use two different deflators: price of total imports of goods and services to deflate imports of intermediate goods, and the deflator for total domestic expenditure concerning final domestic demand. However, neither of these deflators has a sectoral dimension, whereas, in our methodology, trade unit value deflators are calculated according to production stages.

39 Their resulting "GVC structural index" (Haugh et al., 2016, pp. 17-18) shows a steady rise since the 1990s to the 2010. Apart from a slight decline since 2013, the trend reversal of the structural GVC index is much less pronounced than the sharp reduction (starting in 2011) in their GVC indicator before correcting for price effects and cyclical movements (Haugh et al., 2016, Figure 10, p. 18). Therefore, despite differences in the methods used (and the results), Haugh et al. (2016) also find a major influence of commodity prices and business cycle.
} 
Figure 6

Actual and adjusted shares

of Parts \& Components in volume

(at 2011 prices, in \% of manufacturing world trade)

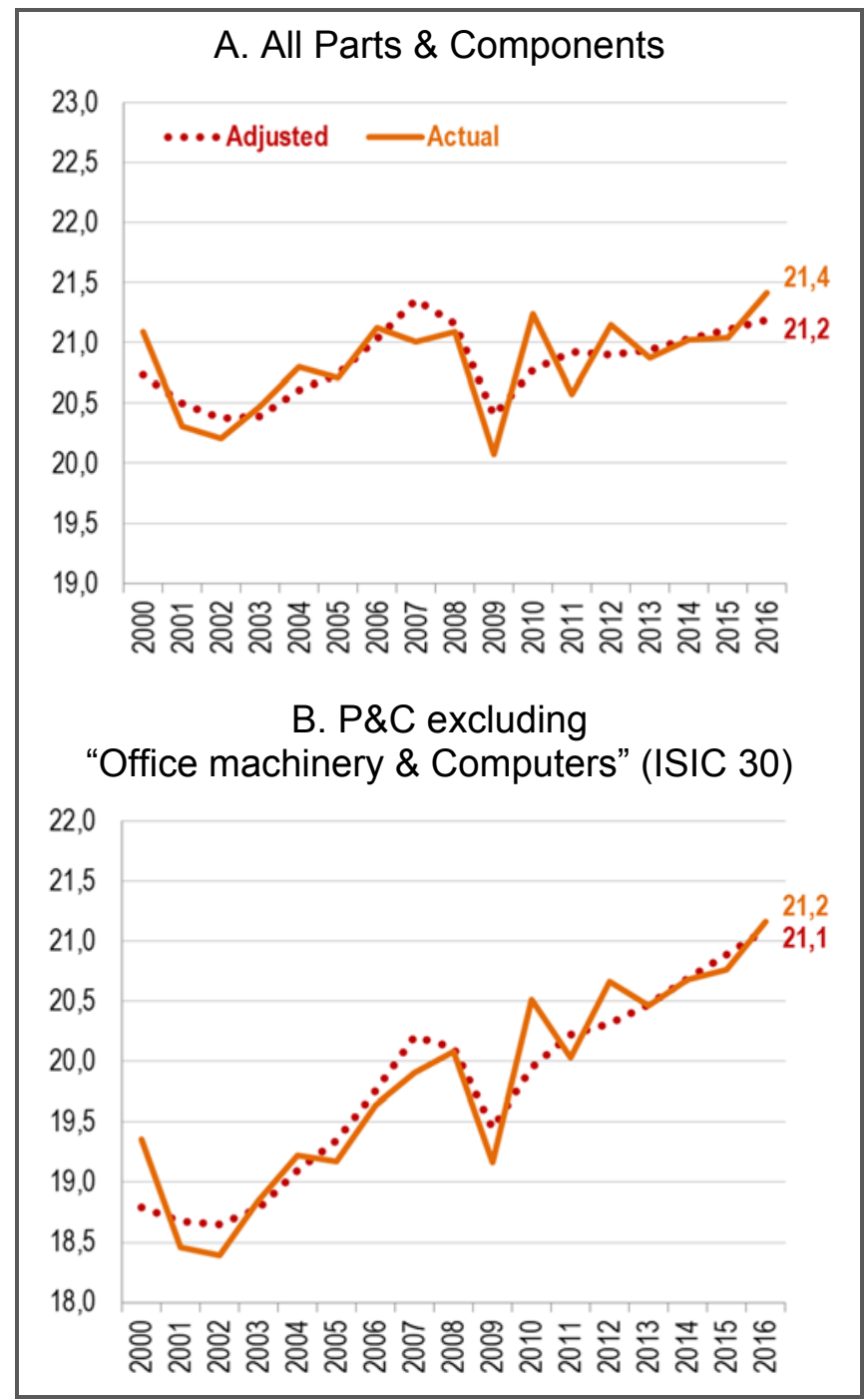

Note: Adjusted share is the fit of the regression of the P\&C share in volume on a linear trend and an output gap from IMF-WEO database (see Appendix 7).

Source: Authors' calculations from CEPII's WTFC database.

\section{GVCs and sectoral developments}

Finally, we investigate whether sectoral composition effects played a role in the evolution of the trade share in volume of P\&C. Is the share of world trade in industries where this stage of production is significant higher in 2016 compared to 2000 ? Or, does the share of P\&C increase within industries?

Figure 7A depicts the evolution in world manufacturing trade in volume by branch groups. In the medium term, trade shares were relatively stable, particularly for branch groups involved in P\&C trade. In this production stage, over the period considered, four branch groups account for more than $96 \%$ of world trade in P\&C (see Figure 7.B) with electronics accounting for $40 \%$ of P\&C trade in 2016. Transport equipment represented $26 \%$ of P\&C trade followed by machinery $18 \%$ and electrical machinery $12 \%$ in 2016 . Thus, there is no evidence of a sectoral 
composition effect on P\&C trade shares. At this level of aggregation, we observe no major changes and the rise in the P\&C trade share in volume is not, as might have been expected, linked to expansion of the electronics industry.

Figure 7.C shows that, within these four main branch groups, P\&C trade shares remained stable (in the case of machinery and electronics) or grew slightly (electrical machinery and transport equipment) throughout the period, with no sign of a slowdown after the Great Recession. In contrast, starting in 2009 in the case of transport equipment and 2011 in the case of electronics, there was an upturn after the 2008-09 global crisis.

Figure 7

World manufacturing trade in volume by branch groups and zoom on P\&C

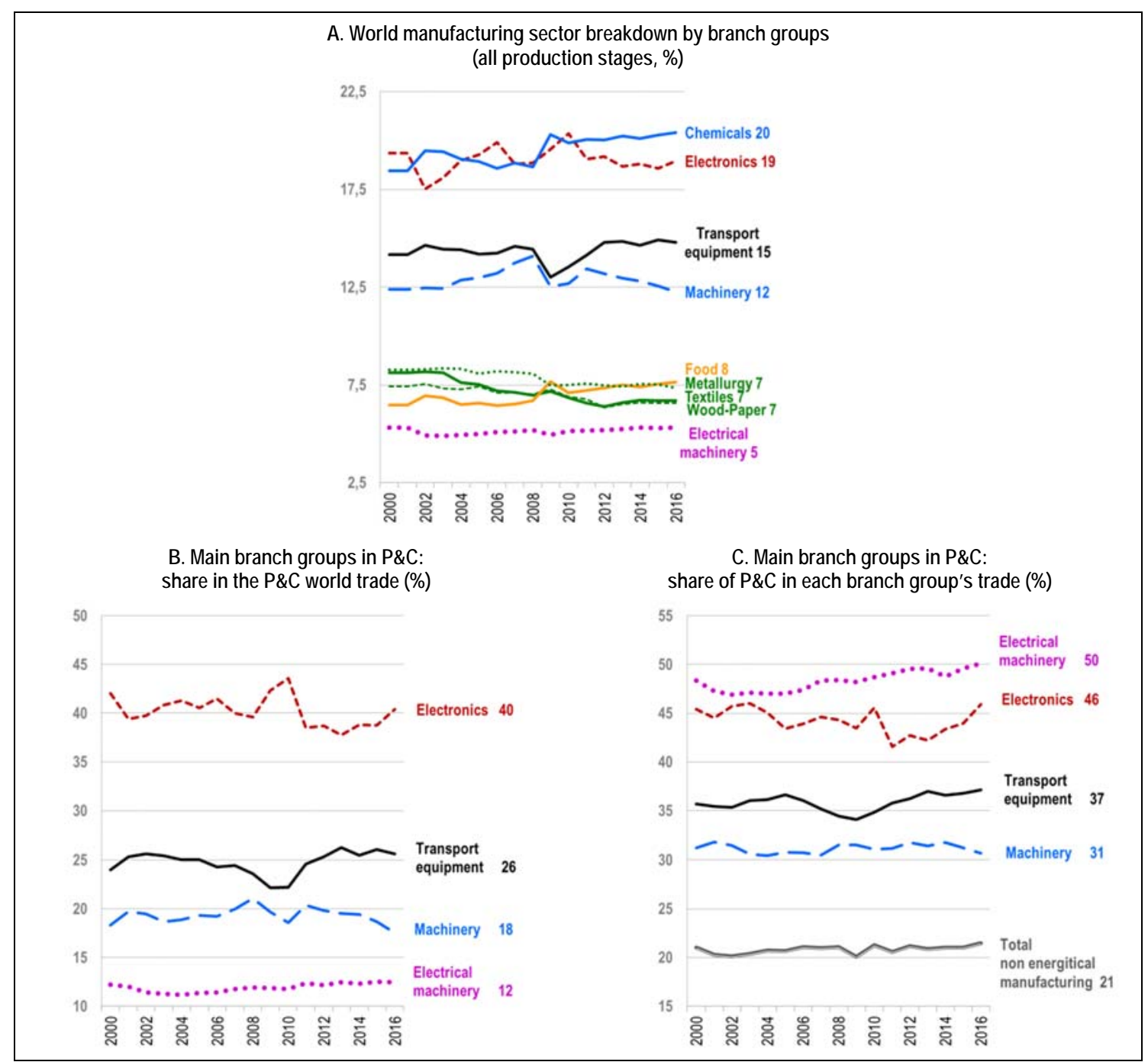

Notes: See Figure A.6 in Appendix 8 for trade shares in value.

Source: Authors' calculations from CEPIl's WTFC database 


\section{Figure 8}

World trade in electronics in volume

(in \% of world manufacturing trade)

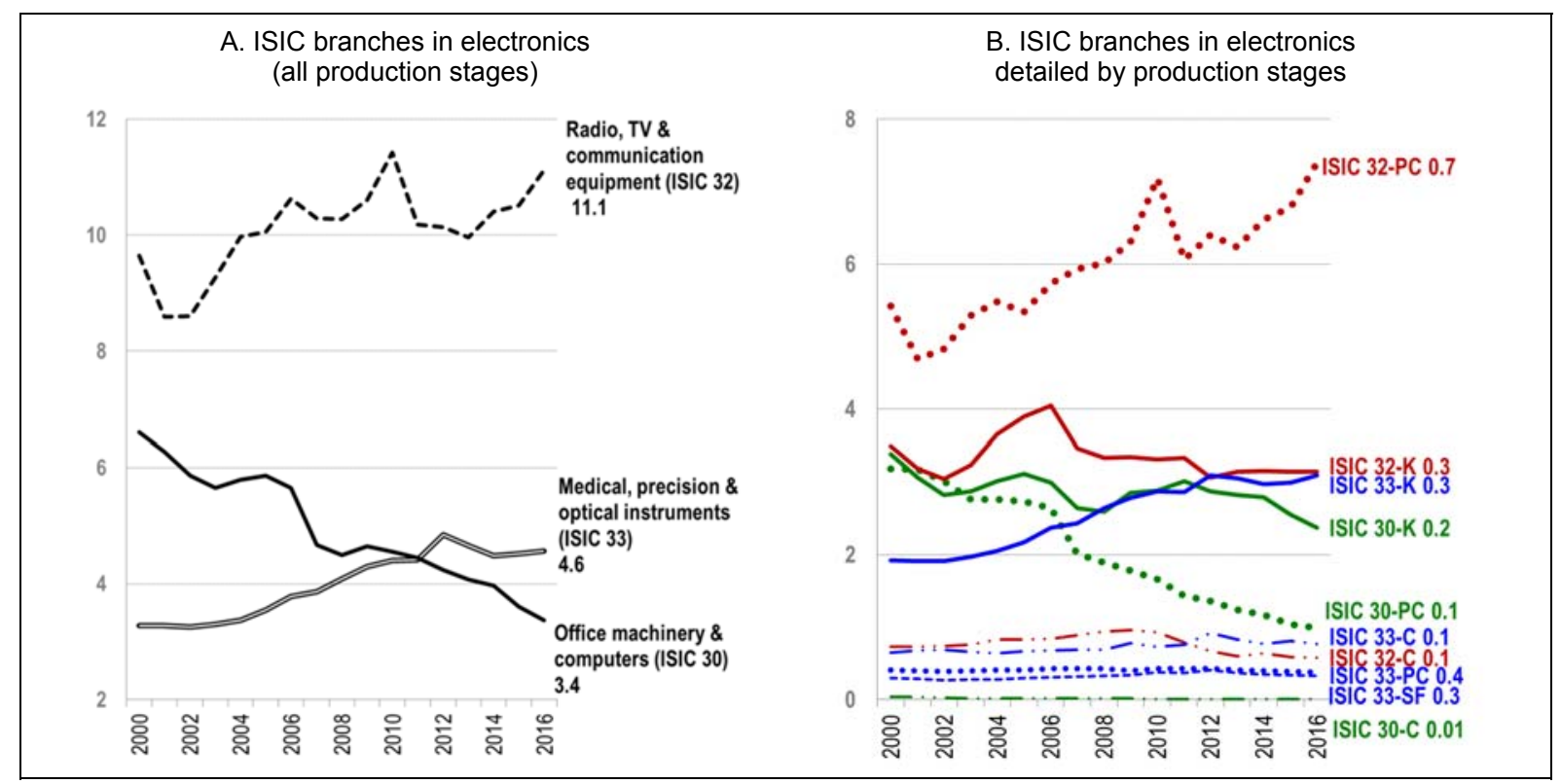

Notes: In panel A HS6 products are regrouped in branches according to 2 digit ISIC classification: ISIC 30 (Office machinery \& computers), 32 (Radio, TV \& communication equipment) and 33 (Medical, precision \& optical instruments). In panel B, these three branches are detailed by production stages: SF, semi-finished goods; PC, P\&C; K, capital goods; and C, consumption goods. See Figure A.7 in Appendix 8 for trade shares in value.

Source: Authors' calculations from CEPII's WTFC database.

Given the high share of electronic products in P\&C trade flows, we explore this sector in more detail, according to branches and production stages. Figure 8.A shows that global stability in electronics is hiding some major changes among branches. Trade shares in volume for telecommunications equipment and precision and medical instruments increased, but decreased in the case of the share of office machinery and computers in world manufacturing trade. These changes are not linked to price effects since similar evolutions are observed in trade shares at current prices (see Appendix 8). In the case of office machinery and computers, the decline is even more pronounced in current prices: -3.4 (from $7.4 \%$ to $4 \%$ ) versus -3.2 (from $6.6 \%$ to $3.4 \%$ ) in volume. Consistent with the smaller increase in the prices of precision and medical instruments, trade shares in volume in this subsector exhibited a higher increase over the period: 1.3 (from $3.3 \%$ to $4.6 \%$ ) compared to 1.1 in value (from $3.9 \%$ to $5 \%$ ). For telecommunications equipment, the slight decrease in the trade share in value $(-0.9$, from $12.1 \%$ to $11.2 \%$ ) becomes a slight increase in volume (+0.5, from $9.6 \%$ to $11.1 \%)$.

A breakdown by production stages indicates that the decline in the trade share of office machinery and computers was linked to a major decrease in $P \& C$ and a more modest decrease in capital goods (see Figure 8.B). Similarly, the rise in telecommunications equipment was driven by $\mathrm{P} \& \mathrm{C}$ growth, and capital goods growth was responsible for the increase in precision and medical instruments.

These changes are linked, in part, to a structural transformation of the electronics sector where the development of telecommunications equipment activities has occurred in parallel with a decrease in the more mature office machinery and computer sectors.

In light of these findings, we re-ran the regressions for share in volume of $\mathrm{P} \& \mathrm{C}$ in world trade, but excluding office machinery and computers (see Figure 6.B) which accounted for a high share of P\&C trade in the electronics industry in 2000 (35\% in volume compared to $11 \%$ in 2016). This subsector includes a diversity of goods and is characterized by rapid technological 
change, which increases the relevance of classification and measurement issues. ${ }^{40}$ As expected, our GVC indicator shows a greater increase when office machinery and computers are excluded.

\section{GVCs at the extensive margin}

More qualitative data on the number of international "links" in production networks allow for more in-depth analysis of GVCs and production stages. Johnson (2017) suggests that the number of links in the GVC can be used to study GVC organization, length, position of industries in the value chain and degree of fragmentation. Johnson (2017) refers to Fally (2012) and Antràs and Chor (2013) who count the number of production stages. Another "qualitative" count statistic in the context of GVCs is growth in the variety of products. Papageorgiou and Spatafora (2012), for the case of Vietnam, find an 18-fold rise in the number of products exported between 1990 and 2010. Other studies measure varieties gains by incorporating growth in the number of varieties in price measures (Feenstra, 1994; Feenstra and Weinstein, 2017).

In the present study, data on the number of clients by exporter, and the number of suppliers by importer, are used to measure geographic diversity along GVCs and the expansion of trade at the extensive margin. A client (respectively a supplier) of an exporter (respectively importer) is a destination (respectively origin) country for a given product. Figure 9 presents numbers and equivalent numbers by production stages, of clients per exporter and suppliers per importer. Average values are computed for countries and products at the 6-digit HS level for manufacturing world trade and for each year in our period of analysis (2000-2016). ${ }^{41}$ Since absolute numbers treat two clients (or suppliers) representing, respectively, $1 / 10000^{\text {th }}$ and $10 \%$ of sales (or purchases) similarly, we also calculate equivalent numbers to obtain further information on the geographic concentration of sales and supply. ${ }^{42}$ Since equivalent numbers give higher weights to larger partners, they are an appropriate statistical indicator to measure diversity in a context of highly heterogeneous country sizes (e.g., the Kiribati Islands compared to Japan). ${ }^{43}$

\footnotetext{
40 Due to an insufficient level of detail in the product classifications, some items have a strong effect on aggregates. For instance, HS 847330 "parts and accessories of data processing equipment not elsewhere specified" contributes a great deal to the decline of the P\&C trade share in volume for office machinery and computers, due to both its declining values and rising unit values.

${ }^{41}$ Note that our measures may underestimate growth at the extensive margin since they do not consider the numbers of clients and suppliers in a country.

${ }^{42}$ The following example shows how equivalent numbers measure partner diversity. If a country has two clients, each accounting for $50 \%$ of export sales, the equivalent number is 2 . If a country has 11 clients and one of them accounts for $90 \%$ of export sales and the other ten each account for $1 \%$, the equivalent number is 1.2 . To find equivalent numbers, we consider simple average values although weighted averages (or medians) can also be calculated. Appendix 9 presents weighted equivalent numbers for manufacturing world trade, using trade at the 6digit HS level as the weight (average over 2000-2016). It also provides the numbers for all world trade products.

${ }^{43}$ However, using this indicator (as well as absolute numbers), replacing two suppliers, one in Italy and one in Germany, by four suppliers in China, reduces diversity. Therefore, this indicator cannot capture firm diversification within a single country. However, considering the high level of concentration of trade among firms at country level, this might not be too much of a problem. Also, our focus is on international, not national fragmentation of the production process.
} 
We observe, first, that the number of international links is increasing, and this applies to each production stage. ${ }^{44}$ Also, apart from a slight slowdown between 2008 and 2012, we find no evidence of weaker growth in geographic diversification since the Great Recession. It is interesting that the greatest geographic diversity is in P\&C - based on either numbers or equivalent numbers, for both clients and suppliers. In contrast, despite an increase since 2000, the lowest values are for semi-finished products. So P\&C trades involves more countries and more border crossings and geographic diversification, and has been rising steadily while diversification in semi-finished products has remained almost unchanged. Also noteworthy is the high level of geographic diversification on the import side in the case of P\&C, regardless of which indicator is used. ${ }^{45}$ This might reflect a GVC organisation where firms source inputs from across the world, but sell output to a limited number of destinations. For example, a Mexican subcontractor of a German carmaker may buy inputs from numerous suppliers, but sell its output exclusively to the US. ${ }^{46}$ In addition, in the context of imports, the flat slopes of the curves of the equivalent numbers for semi-finished products and consumption goods indicate that new suppliers are of small size. It is significant that the gap between the two types of intermediate products is increasing up to $2014 .{ }^{47}$ Figure 10 shows that semi-finished products decline according to all the indicators whereas $P \& C$ show increased supplier diversity. For clients, P\&C show similar dynamics to finished goods. All producers, including $P \& C$ producers, require a high and increasing diversity of suppliers. However, once the parts are combined into a product, the number of clients is no higher for P\&C. Diversified supply of inputs is crucial for monopolistic firms selling a specific variety, whereas (geographical) diversification of sales entails fixed costs related to each destination, which, especially for small and medium sized firms, can reduce the benefits deriving from economies of scale.

\footnotetext{
${ }^{44}$ Note that the increase in our indicators cannot be due to the emergence of new countries or new products since our calculations are based only on countries and products available in each of the years in the 2000-2016 period. It implies that, during our period of analysis starting in 2000, there were very few withdrawals of products or countries.

${ }^{45}$ In the case of imports, using weighted equivalent numbers leads to the same result (see Appendix 9). In the case of exports, equivalent numbers are more similar for P\&C and capital goods.

${ }^{46}$ Supplier diversity at the country level stems from both the number of suppliers of a representative firm and the number of firms, each of which will have preferred suppliers.

47 The figures for years 2015 and 2016 should be interpreted with caution since these recent data may not be exhaustive and are subject to revision (due, in particular, to missing data for some countries in recent releases). Therefore, the slight decline observed in our indicators for these two years could be attributable to statistical issues as well as the relative weakness of Asian trade and cyclical factors. Further research will be needed to study the more recent evolutions.
} 
Figure 9

Clients and suppliers diversity:

average values levels by production stages in manufacturing world trade (calculated by countries and products at the 6-digit HS level)

A. CLIENTS BY EXPORTER

B. SUPPLIERS BY IMPORTER

Number
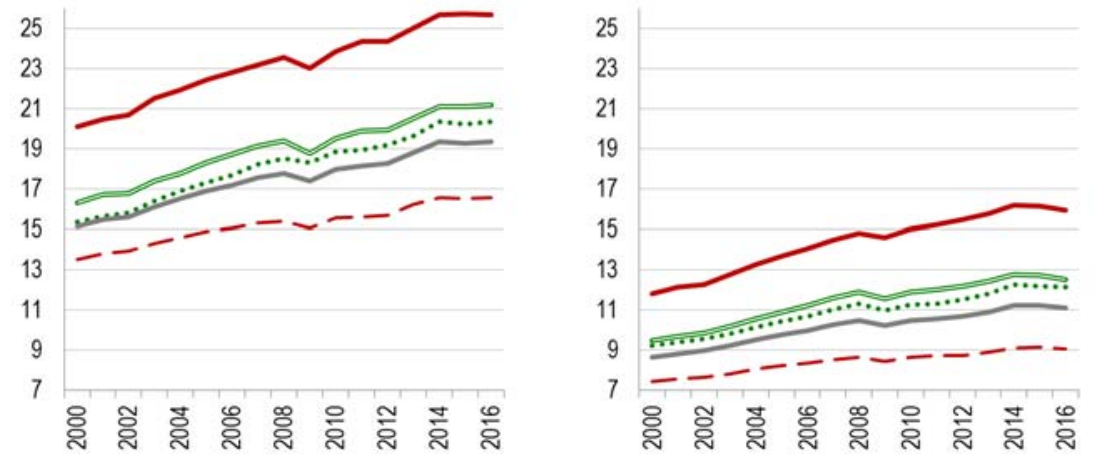

Equivalent number
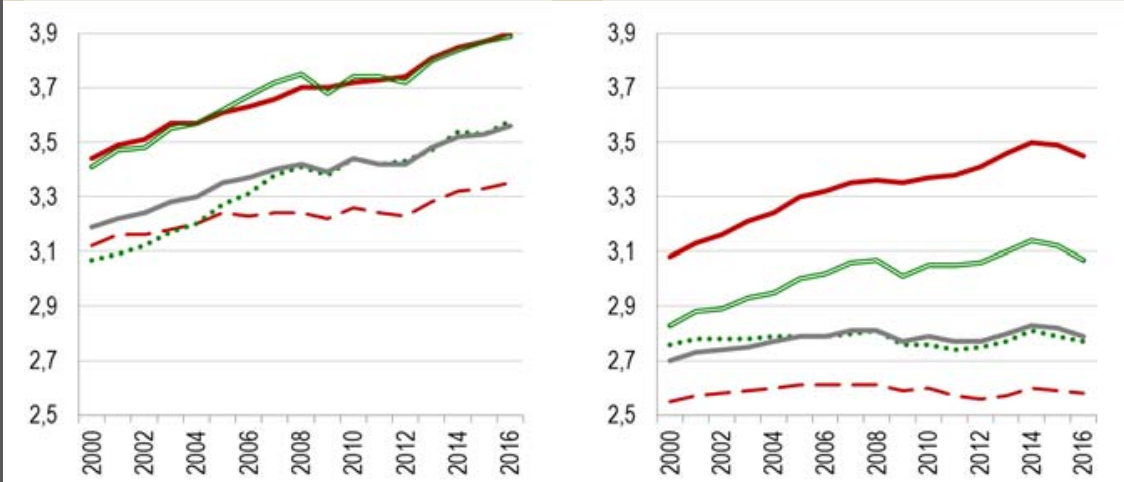

---Semi-Finished

$\longrightarrow P \& C$

Consumption

Capital $\longrightarrow$ Total

Notes: Equivalent numbers are computed for each country and product at the 6-digit HS level according to the

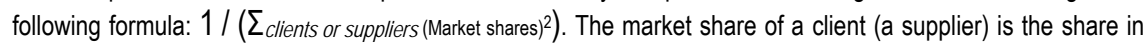
total exports (imports) of this client (supplier). Calculations are made only for countries and products available for each year of the 2000-2016 period.

Source: Authors' calculations from CEPII's WTFC database. 


\section{Figure 10}

Clients and suppliers diversity: average value indices by production stages in manufacturing world trade (calculated by countries and products at the 6-digit HS level, 2000=1)

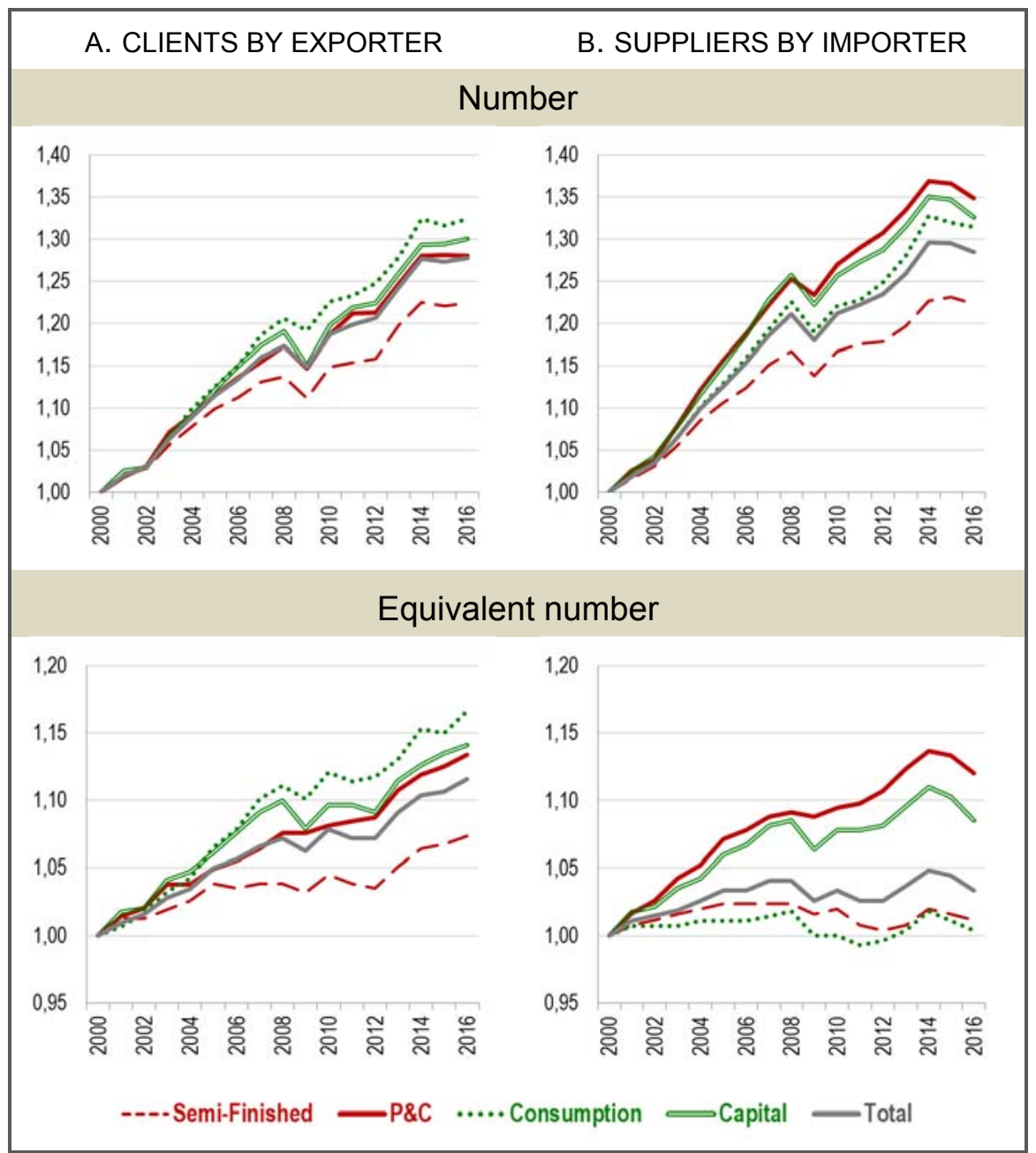

Notes: Equivalent numbers are computed for each country and product at the 6-digit HS level according to the

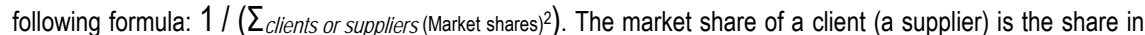
total exports (imports) of this client (supplier). Calculations are made only for countries and products available for each year of the 2000-2016 period.

Source: Authors' calculations from CEPII's WTFC database. 


\section{Conclusion}

This working paper provided an in-depth examination of GVC dynamics at world level since the 2000s. We used very detailed trade data for the period 2000 to 2016, distinguishing different production stages along the GVC. We focused on P\&C trade flows which capture GVC dynamics better than total intermediate goods. We took account of price effects by constructing an original deflator by production stages. Price fluctuations shape trade share dynamics to varying extents in the downstream and upstream stages. We controlled, also, for the global business cycle given the heterogeneous degrees of procyclicality across production stages.

Our findings are as follows:

Our GVC indicator, namely share in volume of $P \& C$ in manufacturing trade, was on a slightly upward trend over the period and showed no sign of reversal in the most recent years. These dynamics are not the result of a sectoral composition effect.

In the electronics sector, where GVCs are particularly developed, we observed contrasting developments: the share in P\&C trade for office machinery and computers decreased, but increased for telecommunications equipment, the IT revolution flagship industry.

Counts of clients or suppliers by stages of production also indicate a higher and growing geographical diversity for P\&C.

GVCs will remain at the centre of future economic debates and, especially, in the context of the recent protectionist tensions and regional disintegration pressures in NAFTA and the EU.

It is clear that a sound understanding of GVC evolutions and reliable and up-to-date measures of this phenomenon are crucial for analyses of the globalization process. 


\section{Appendices}

\section{Appendix 1 Results from a Google Scholar search of GVCs}

Figure A.1 Results from a Google Scholar search of "global value chains", 1980-2017

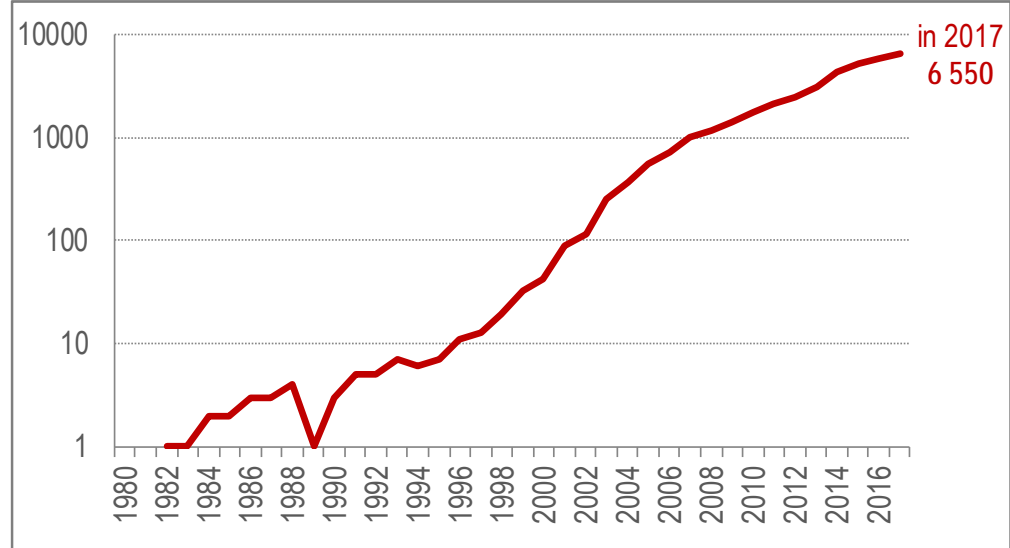

Notes: Number of entries as a result of a Google Scholar search of the exact phrase "global value chains". Search conducted on 23 May 2018 (logarithmic scale).

Source: https://scholar.google.fr/ 


\section{Appendix 2 Construction of WTFC database from TUV and BACI databases}

The TUV relies on Tariff lines data, provided by the United Nations Statistical Division and provide raw information on trade values and quantities as reported by the declaring countries, for 173 reporters and 255 partner countries. Each country declares both imports (CIF) and exports (FOB). Raw declarations do not allow for international comparative analyses: quantity units, thresholds and levels of aggregation vary according to the reporter. Data are processed in order to provide reliable and comparable unit values across countries. First, all quantity units are converted into weights, using conversion factors computed from UN COMTRADE mirror flows (quantities declared in different units by the exporter and the importer provide empirical conversion). Second, extreme unit values are detected using the cross-sectional and the time dimensions of the data. Third, unit values are computed as the ratio of values on quantities. Finally, unit values (in US dollars per ton) are aggregated at the HS6-digit level. We end up with a worldwide unit values database, covering 182 reporters, 253 partners, and more than 5,000 product categories. (Emlinger and Piton, 2014, p. 2)

[WTFC]... harmonize the Trade Unit Values database following BACl methodology. Harmonization takes advantage of the double information for each flow we have in the Trade Unit Values database, comparing import unit values (relying on importers' declarations) and export unit values (relying on exporters' declarations) for the same flow (i.e. mirror flows). TUV harmonization raises two concerns. First, as import unit values are reported including all trade costs (except tariffs and domestic taxes after the border) while exports are reported FOB (free on board), we cannot directly compare exporters' and importers' declarations. We thus use CIF (cost of insurance and freight) rates estimates of BACI to compute FOB import unit values. Second, as all country reports do not have the same accuracy, a criterion to average the FOB-FOB mirror numbers is needed. We use the reliability of each country provided by $\mathrm{BACl}$ to weight and reconcile each mirror trade flow. In $\mathrm{BACl}$, the reliability of countries' report is evaluated by computing an indicator of the reporting distance among partners (the absolute value of the natural log of the ratio of mirror flows). This indicator is then decomposed using a (weighted) variance analysis. The relative reliability of country reporting is then cleaned from the effects of its geographical and sectoral specialization. (Emlinger and Piton, 2014, p.3)

The interest of using the World Trade Flows Characterization (WTFC), this harmonized version of the TUV is twofold. First, using TUV database improves the quality and offers more reliable and consistent unit values than the UN COMTRADE database, the latter suffering from biases in the computation of unit values. Indeed, the treatment of countries' reports by UN Statistical Division in case of missing information regarding quantities reduces the variance of unit values observed: missing weights are estimated using the mean unit value recorded for the same reporter and product category or, when it is not possible, using a standard unit value computed at the world level. In this latter case, all countries are assumed to share the same price for a given HS6-digit product category, that leads to smaller unit values variance for this product. As a consequence, in BACl database (which results from the harmonization of the UN COMTRADE database), 63\% of world trade corresponds to unit values in the median quartile, whereas it is $57 \%$ in the harmonized version of TUV. Second, the harmonization of TUV increases the quantity of unit values documented and increases the coverage of our database, benefiting from the double information for each flow we have in TUV as stated previously. This harmonization compensates for one of TUV's main setback, which is that using raw data decreases the number of documented unit values: TUV database only covers $79 \%$ of the flows existing in the UN COMTRADE database on average. (Emlinger and Piton, 2014, p.3) 
Appendix 3 Classifications by stages of production, branch groups and branches

Table A.1

Classification by production stages

\begin{tabular}{l|c|l}
\hline Production stages & Code BEC* & BEC Name \\
\hline \multirow{3}{*}{ Primary products } & 111 & Food and beverages, primary, mainly for industry \\
& 21 & Industrial supplies n.e.s., primary \\
& 31 & Fuels and lubricants, primary \\
\hline \multirow{3}{*}{ Semi-finished products } & 121 & Food and beverages, processed, mainly for industry \\
& 22 & Industrial supplies n.e.s., processed \\
\hline Parts \& components & 322 & Fuels and lubricants, processed \\
\hline Capital goods & 42 & Of capital goods, except transport equipment \\
& 43 & Of transport equipment \\
\hline & 521 & Capital goods except transport equipment \\
& 112 & Other industrial transport equipment \\
\hline \multirow{2}{*}{ Consumption goods } & 122 & Food \& bev., primary, mainly for household consumption \\
& 51 & Food \& bev., primary, processed, for house. consumption \\
& 522 & Other non-industrial transport equipment \\
& 61 & Durable consumer goods n.e.s. \\
& 62 & Semi-durable consumer goods n.e.s. \\
\hline
\end{tabular}

* Broad Economic Categories of the United Nations.

Source: United Nations Statistics Division (http://unstats.un.org/unsd/cr/registry). 
Table A.2

World trade breakdown by branch groups, branches and production stages (trade in value, all products, average $2000-2016$, in \% of total)

\begin{tabular}{|c|c|c|c|c|c|c|c|}
\hline \multirow[b]{2}{*}{ Branch group / ISIC Rev. 3 branch } & \multicolumn{7}{|c|}{ Production stages (BEC groupings) } \\
\hline & Commodities & $\begin{array}{c}\text { Semi- } \\
\text { finished }\end{array}$ & $\mathrm{P \& C}$ & Consumption & Capital & NEC & Total \\
\hline TOTAL & 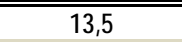 & 29,3 & 16,7 & 22,1 & 16,8 & $1,1,5$ & 100,0 \\
\hline Energy & 9,2 & 5,5 & & & & & 14,7 \\
\hline 10 Mining of coal \& lignite & 0,6 & 0,0 & & & & & 0,6 \\
\hline 11 Extraction of crude petroleum \& natural gas & 8,6 & 0,6 & & & & & 9,2 \\
\hline 12 Mining of uranium \& thorium ores & 0,0 & & & & & & 0,0 \\
\hline 23 Coke, refined petroleum \& nuclear fuel & 0,0 & 4,6 & & & 0,0 & & 4,6 \\
\hline 40 Electricity, gas, steam \& hot water supply & 0,0 & 0,2 & & & & & 0,2 \\
\hline Agriculture \& Food & 1,9 & 1,2 & & 5,2 & 0,0 & & 8,4 \\
\hline 01 Agriculture, hunting & 1,6 & 0,0 & & 1,0 & 0,0 & & 2,6 \\
\hline 02 Forestry, logging & 0,1 & 0,0 & & & & & 0,2 \\
\hline 05 Fishing, fish farming & 0,0 & & & 0,1 & & & 0,2 \\
\hline 15 Food products \& beverages & 0,1 & 1,2 & & 3,9 & & & 5,2 \\
\hline 16 Tobacco products & & & & 0,2 & & & 0,2 \\
\hline Textiles & 0,0 & 1,4 & 0,0 & 4,0 & & 0,0 & 5,5 \\
\hline 17 Textiles & 0,0 & 1,2 & 0,0 & 1,1 & & 0,0 & 2,3 \\
\hline 18 Wearing apparel & & 0,0 & & 2,0 & & & 2,0 \\
\hline 19 Leather & & 0,2 & 0,0 & 1,0 & & & 1,2 \\
\hline Wood Paper & 0,1 & 2,8 & 0,0 & 2,3 & 0,3 & 0,0 & 5,6 \\
\hline 20 Wood products & 0,0 & 0,7 & & 0,0 & & & 0,8 \\
\hline 21 Pulp, paper \& paper products & 0,1 & 1,2 & & 0,2 & & & 1,4 \\
\hline 22 Publishing, printing \& recorded media & & 0,1 & 0,0 & 0,4 & & & 0,5 \\
\hline 36 Furniture; manufacturing n.e.c. & 0,0 & 0,8 & 0,0 & 1,7 & 0,3 & 0,0 & 2,9 \\
\hline Chemicals & 0,6 & 10,6 & 0,5 & 3,8 & & & 15,4 \\
\hline 14 Other mining \& quarrying & 0,5 & & & & & & 0,5 \\
\hline 2410 Basic chemical products & 0,0 & 5,2 & & & & & 5,2 \\
\hline 2423 Pharmaceutical products & & 1,3 & & 2,0 & & & 3,3 \\
\hline $24 \times x$ Other chemical products & & 1,8 & & 1,0 & & & 2,8 \\
\hline 25 Rubber \& plastic & 0,0 & 1,2 & 0,5 & 0,7 & & & 2,5 \\
\hline 26 Non-metallic mineral products & 0,0 & 1,0 & 0,0 & 0,1 & & & 1,1 \\
\hline Metallurgy & 1,6 & 5,2 & & & & & 6,8 \\
\hline 13 Mining of metal ores & 1,5 & & & & & & 1,5 \\
\hline 27 Basic metals & 0,1 & 5,2 & & & & & 5,3 \\
\hline Machinery & & 1,6 & 3,2 & 0,9 & 4,6 & 0,1 & 10,3 \\
\hline 28 Metal products & & 1,5 & 0,3 & 0,2 & 0,2 & 0,0 & 2,2 \\
\hline 29 Machinery & & 0,1 & 2,9 & 0,7 & 4,4 & 0,1 & 8,1 \\
\hline Electrical machinery & & 0,7 & 2,0 & 0,1 & 1,3 & & 4,0 \\
\hline 31 Electrical machinery & & 0,7 & 2,0 & 0,1 & 1,3 & & 4,0 \\
\hline Electronics & & 0,3 & 6,8 & 1,2 & 7,5 & & 15,8 \\
\hline 30 Office machinery \& computers & & & 1,4 & 0,0 & 2,5 & & 3,9 \\
\hline 32 Radio, TV \& communication equipment & & & 5,0 & 0,6 & 2,7 & & 8,4 \\
\hline 33 Medical, precision \& optical instruments & & 0,3 & 0,3 & 0,6 & 2,3 & & 3,5 \\
\hline Transport equipment & 0,0 & & 4,2 & 4,5 & 3,1 & 0,0 & 11,8 \\
\hline 34 Motor vehicles, trailers \& semi-trailers & & & 3,0 & 4,3 & 1,2 & & 8,5 \\
\hline 35 Other transport equipment & 0,0 & & 1,2 & 0,3 & 1,9 & 0,0 & 3,4 \\
\hline Non elsewhere classified (NEC) & 0,0 & 0,1 & 0,0 & 0,0 & 0,0 & 1,4 & 1,6 \\
\hline 74 Other business activities & & 0,0 & & & & & 0,0 \\
\hline 92 Recreational, cultural \& sporting activities & & 0,1 & & 0,0 & & & 0,1 \\
\hline 93 Other service activities & 0,0 & & & & & & 0,0 \\
\hline XX Other NEC & & & & & & 1,4 & 1,4 \\
\hline
\end{tabular}

Source: Authors' calculations from CEPII's WTFC database. 


\section{Appendix 4 GVCs and regional trade integration}

Since international production networks are frequently organised on a regional basis, GVCs tend to be mainly regional value chains (Baldwin and Lopez-Gonzalez, 2013; Cingolani et al., 2018; Degain et al., 2017; Pomfret and Sourdin, 2018). In this appendix, we examine intraregional and interregional trade shares for P\&C. Figure A.2 provides a geographical breakdown of world trade in $\mathrm{P} \& \mathrm{C}$, distinguishing the three major regional production networks and the rest of the world. Intra- and extra-zone trade flows are detailed for NAFTA, the EU-28 and Factory Asia. The strongest GVC expansion occurred in intra-Factory Asia. In 2000, it represented $19 \%$ of $P \& C$ world trade and reached $30 \%$ in 2016 , compared to $22 \%$ and $19 \%$ for intra-EU. The intra-NAFTA share declined sharply (14\% in 2000 and $8 \%$ in 2016). This fall might be linked to the lack of trade integration deepening in NAFTA over the period studied, ${ }^{48}$ whereas the monetary union and the enlargements towards Central and Eastern Europe further integrated the EU. In the context of Factory Asia, trade integration began to catch up after 2000 based on the signing of numerous trade agreements (Hofmann et al., 2017). Johnson and Noguera (2017) and Laget et al. (2018) show that deeper trade integration is associated to GVC expansion, while Fontagné and Santoni (2018) point to a reverse causality of GVCs and the propensity to sign trade agreements. Hofmann et al. (2018, p. 25) suggest that "The increase in average depth of PTAs over time goes together with the increase in trade of parts and components in the world".

Figure A.2

Geographical breakdown of the world P\&C trade: NAFTA-EU28-Factory Asia-Rest of the world

(with the detail of intra- and extra-zone trade flows, in \% of the world P\&C trade in value)

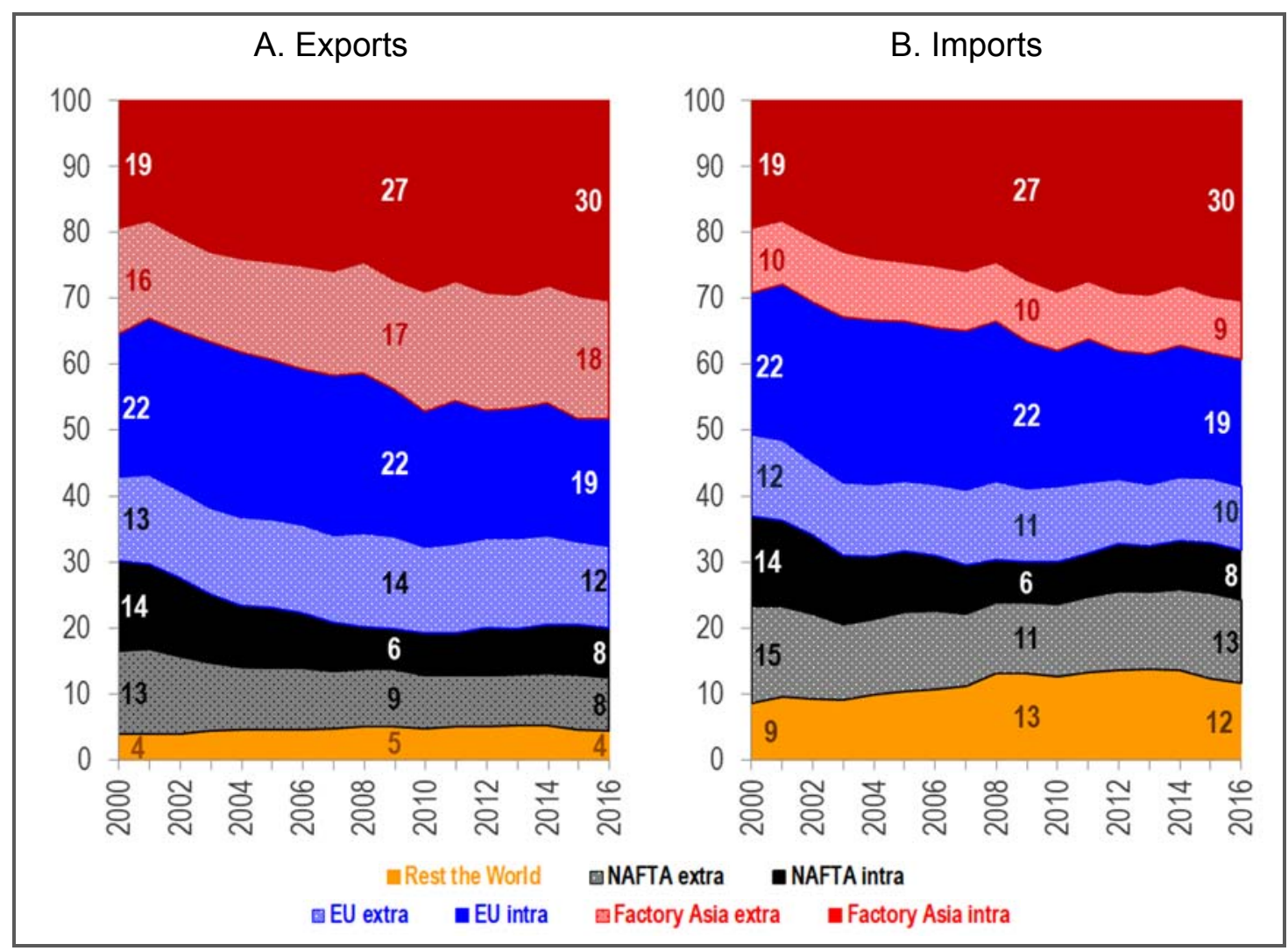

Notes: By construction, intra-regional shares are the same for exports and imports. The Factory Asia region regroups ASEAN member countries (Indonesia, Malaysia, Philippines, Singapore, Thailand, Brunei, Vietnam, Laos, Burma, Cambodia) and China, India, Taiwan, Hong Kong, South Korea, Japan, Australia and New Zealand.

\footnotetext{
48 Dollar depreciation vis-à-vis the euro may have contributed to this evolution.
} 
Source: Authors' calculations from CEPII's WTFC database.

Appendix 5 World trade breakdown by production stages in all products (value \& volume)

Figure A.3

World trade breakdown by production stages in all products

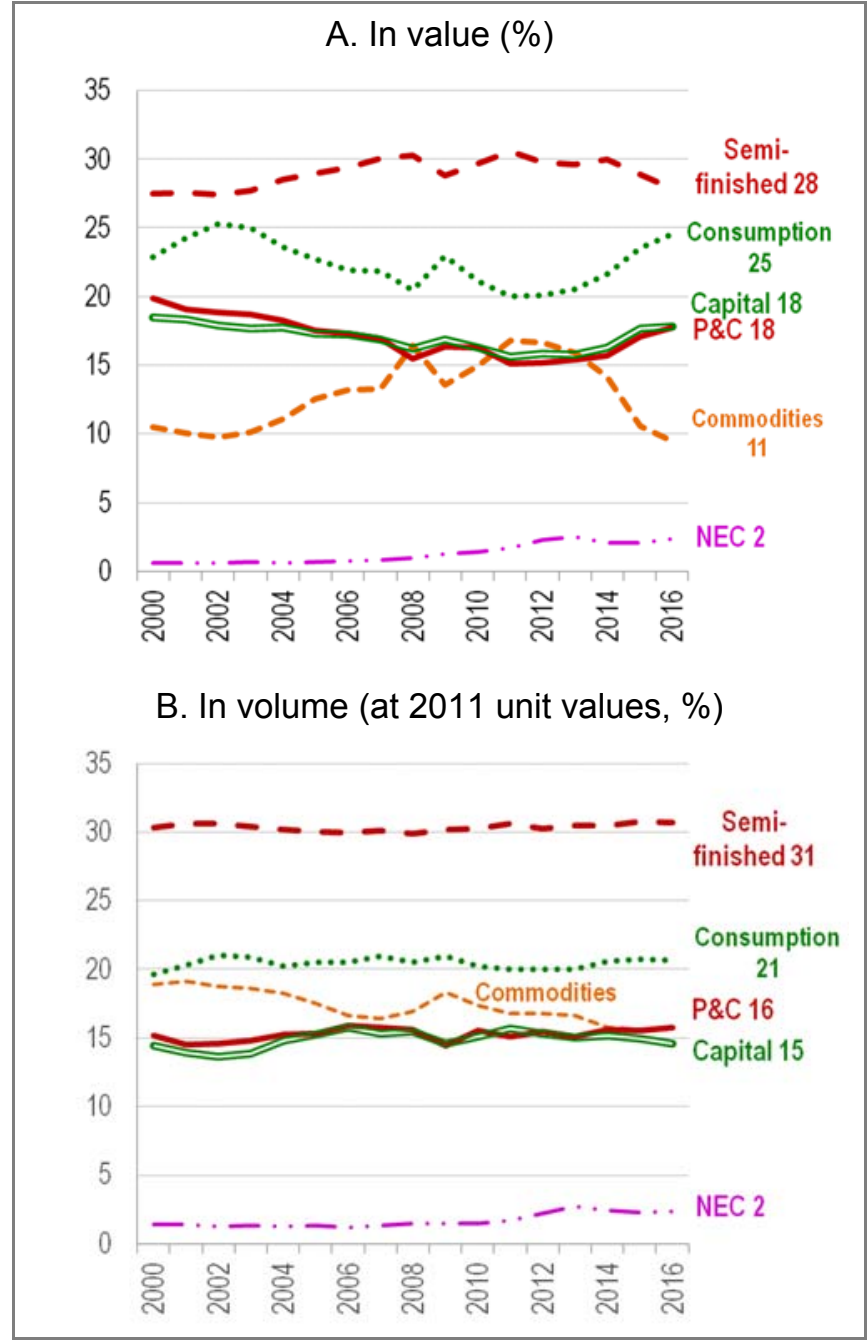

* Intermediate goods $=$ semi-finished products + P\&C.

Source: Authors' calculations from CEPII's WTFC database. 


\section{Appendix 6 Unit value indices calculation}

- Trade data come from the WTFC dataset (see Appendix 2).

- Logarithmic changes in unit-value (value in USD divided by quantity in tons) are computed for each elementary trade flow (i.e. an exporter $i$, an importer $j$, a product hs6 and a year $t$ ).

- To exclude outliers, the top and bottom $5 \%$ logarithmic change (dlog) are dropped, for each product and each year.

- These logarithmic changes in unit-value (dlog) at the 6-digit HS level (around 5,000 products) are aggregated from the bilateral to the world level, using a Tornqvist priceindex formula:

where

$$
d \log T_{h s 6, t}=\sum_{i, j} w e i g h t_{i, j, h s 6, t} * \operatorname{dlog}\left(U V_{i, j, h s 6, t}\right)
$$

$$
\text { weight }_{i, j, h s 6, t}=\frac{1}{2} *\left(\frac{\text { Value }_{i, j, h s 6, t}}{\sum_{i, j} \text { Value }_{i, j, h s 6, t}}+\frac{\text { Value }_{i, j, h s 6, t-1}}{\sum_{i, j} \text { Value }_{i, j, h s 6, t-1}}\right)
$$

(i.e., simple average of the elementary trade flow share in world trade of the specific product at time $t$ and $t-1$ )

The same formula is used to aggregate at the sectoral level (stage of production, industry, industry $\times$ stage, total world trade, etc.). For instance, in the case of production stages (using the United Nations Broad Economic Categories):

$$
d \log T_{b e c, t}=\sum_{h s 6 \in b e c} \text { weight }_{h s 6, t} * d \log T_{h s 6, t}
$$

where:

$$
\text { weight }_{h s 6, t}=\frac{1}{2} *\left(\frac{\text { Value }_{h s 6, t}}{\sum_{h s 6 \in \text { bec } \text { Value }_{h s 6, t)}}}+\frac{\text { Value }_{h s 6, t-1}}{\sum_{h s 6 \in \text { bec }_{\text {Value }} \text { }_{s 6, t-1)}}}\right)
$$

- In the case that the 6-digit unit value are unknown, we use an index at the 4-digit level, or 2-digit if the 4-digit unit value are unknown;

- $T_{\text {bec, }}$ series are computed from dlog $T_{\text {bec, }}$ with 2011 as the base year $\left(T_{\text {hs } 6,2011}=1\right)$;

- "Volumes" are Value ${ }_{b e c, t} / T_{b e c, t}$.

Deflators and trade in volume can be computed at any level of aggregation. ${ }^{49}$ Trade unit value indices by production stages are presented in Figure A.4: after commodities, semi-finished products are the stage of production most affected by price variations, P\&C being the least affected.

\footnotetext{
${ }^{49}$ Note that, the calculation of our deflators, leads to a difference between the sum of trade in volume by production stages and total trade volume. This problem is related to the use of chained weighted methodologies, which minimizes substitution bias, but are not additive. For a more detailed explanation, based on US data, see https://www.census.gov/foreign-trade/aip/priceadj.html.
} 


\section{Figure A.4}

Trade unit value indices by production stages $(2000=1$, world trade, all products)

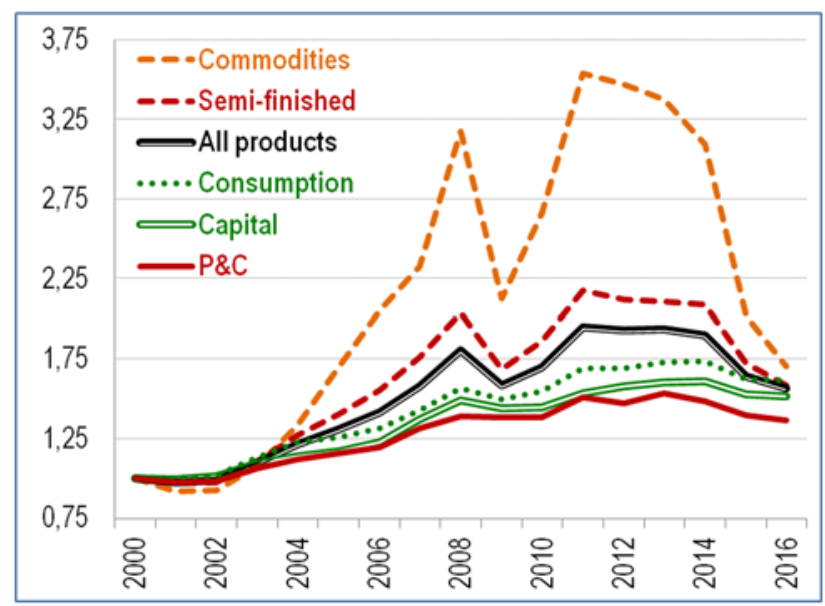

Source: Authors' calculations from CEPII's WTFC database.

If we compare our trade unit value index to other unit value and price indices (Figure A.5), the index matches fairly well. Pooling all products, we can match the world price series provided by CPB in World Trade Monitor and UNCTAD's unit value export index (and, to a lesser extent, UNCTAD's unit value imports index), which is reassuring. The differences between the WDI $\mathrm{CPI}$ and WDI GDP deflators are linked to the inclusion of services in these price indicators.

Figure A.5

World trade unit value (UV), consumer price (CPI) and GDP's price indices

(2011=1)

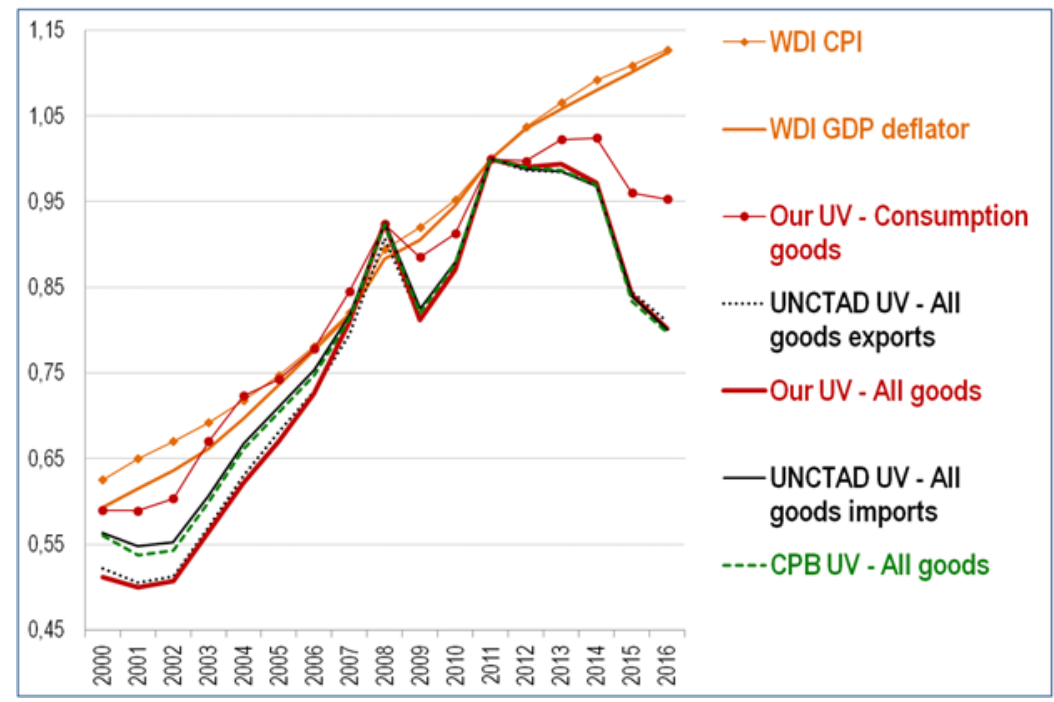

Source: authors' calculations from CEPII's WTFC data base, CPB World Trade Monitor, UNCTAD-STAT, and Word Bank-World development indicators. 


\section{Appendix 7 GVCs and business cycles}

Table A.3

1. Dependent Variable: Trade share of all parts and components (LOG)

\begin{tabular}{|c|c|c|c|c|}
\hline Variable & Coefficient & Std. Error & t-Statistic & Prob. \\
\hline WORLD OUTPUT GAP & 0,010 & 0,003 & 3,698 & 0,002 \\
\hline TREND & 0,003 & 0,001 & 4,059 & 0,001 \\
\hline Intercept & $-1,589$ & 0,006 & $-264,906$ & 0,000 \\
\hline R-squared & 0,609 & & Mean dependent var & $-1,569$ \\
\hline Adjusted R-squared & 0,553 & & S.D. dependent var & 0,019 \\
\hline S.E. of regression & 0,012 & & Akaike info criterion & $-5,772$ \\
\hline F-statistic & 10,895 & & Durbin-Watson stat & 2,794 \\
\hline Prob(F-statistic) & 0,001 & & & \\
\hline
\end{tabular}

2. Dependent Variable:

Trade share of P\&C excluding "Office machinery \& Computers" - ISIC 30 (LOG)

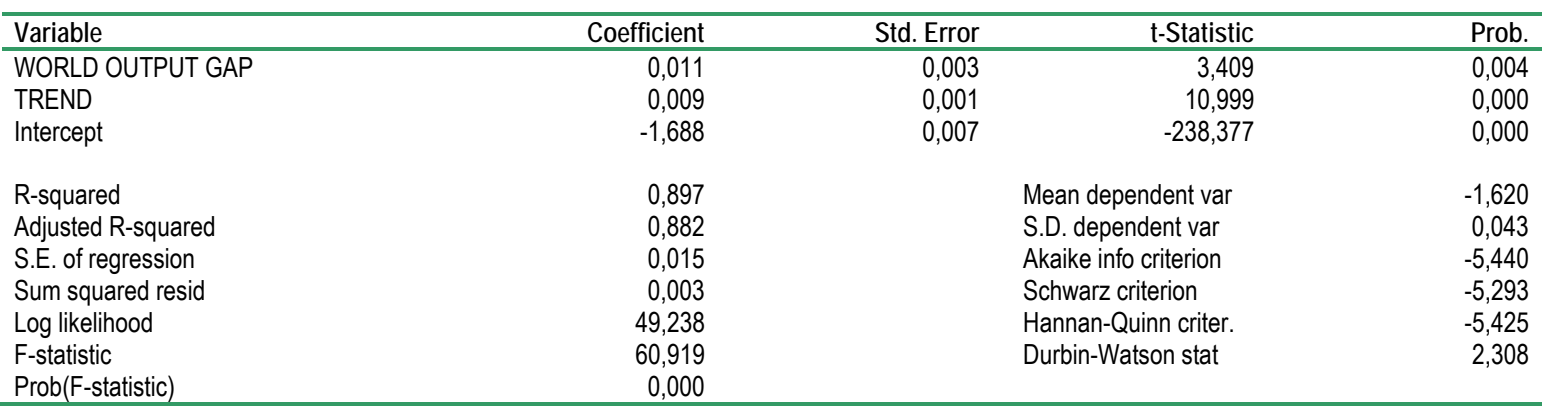

Notes: Least squares method, 17 observations.

Source: Authors' calculations from CEPII's WTFC database and IMF (2017, variable world output gap). 


\section{Appendix 8 Sectoral evolutions}

Figure A.6

World manufacturing trade in value by branch groups and zoom on P\&C

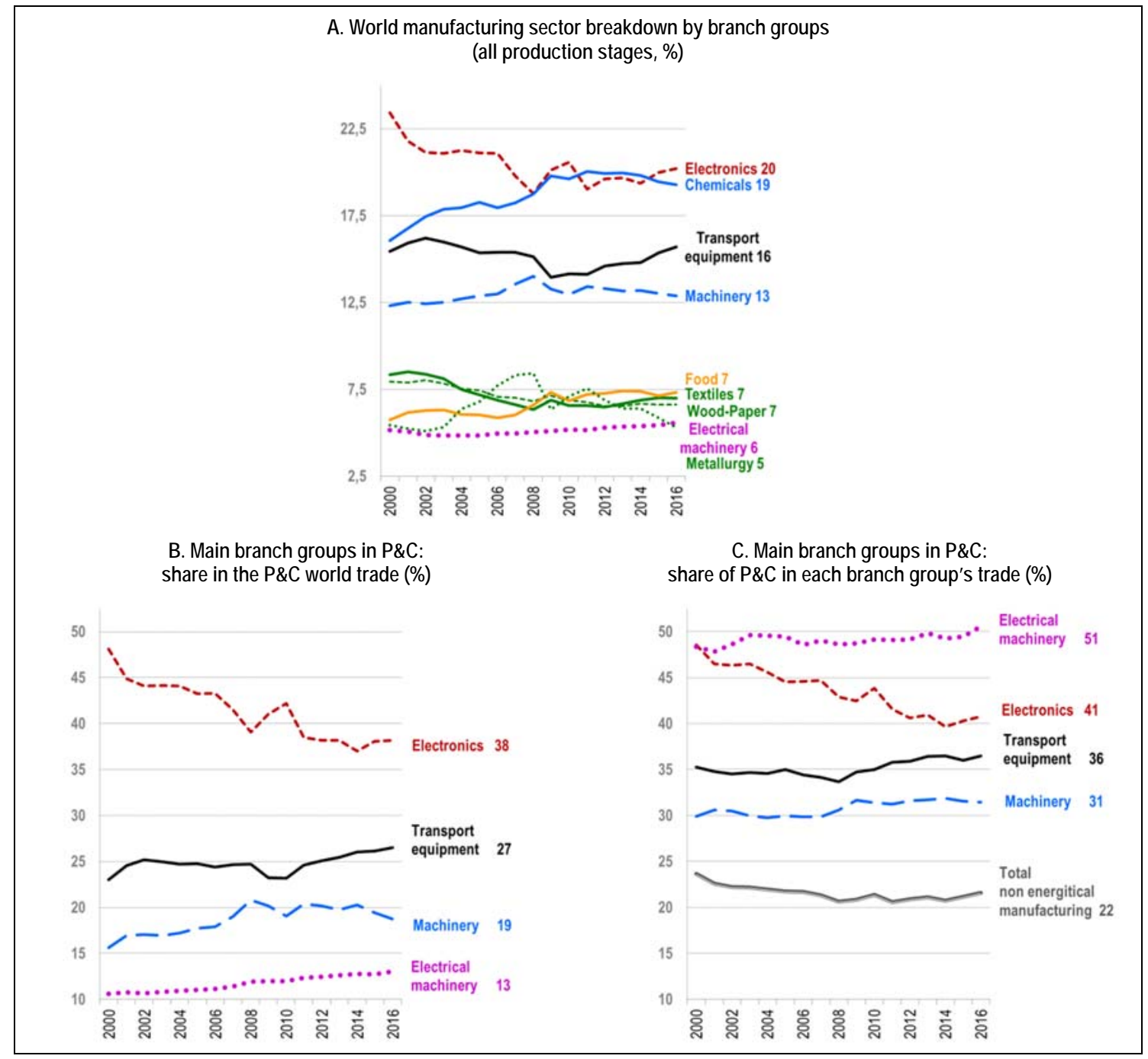

Source: Authors' calculations from CEPII's WTFC database 
Figure A.7

World trade in electronics in value

(in \% of world manufacturing trade)

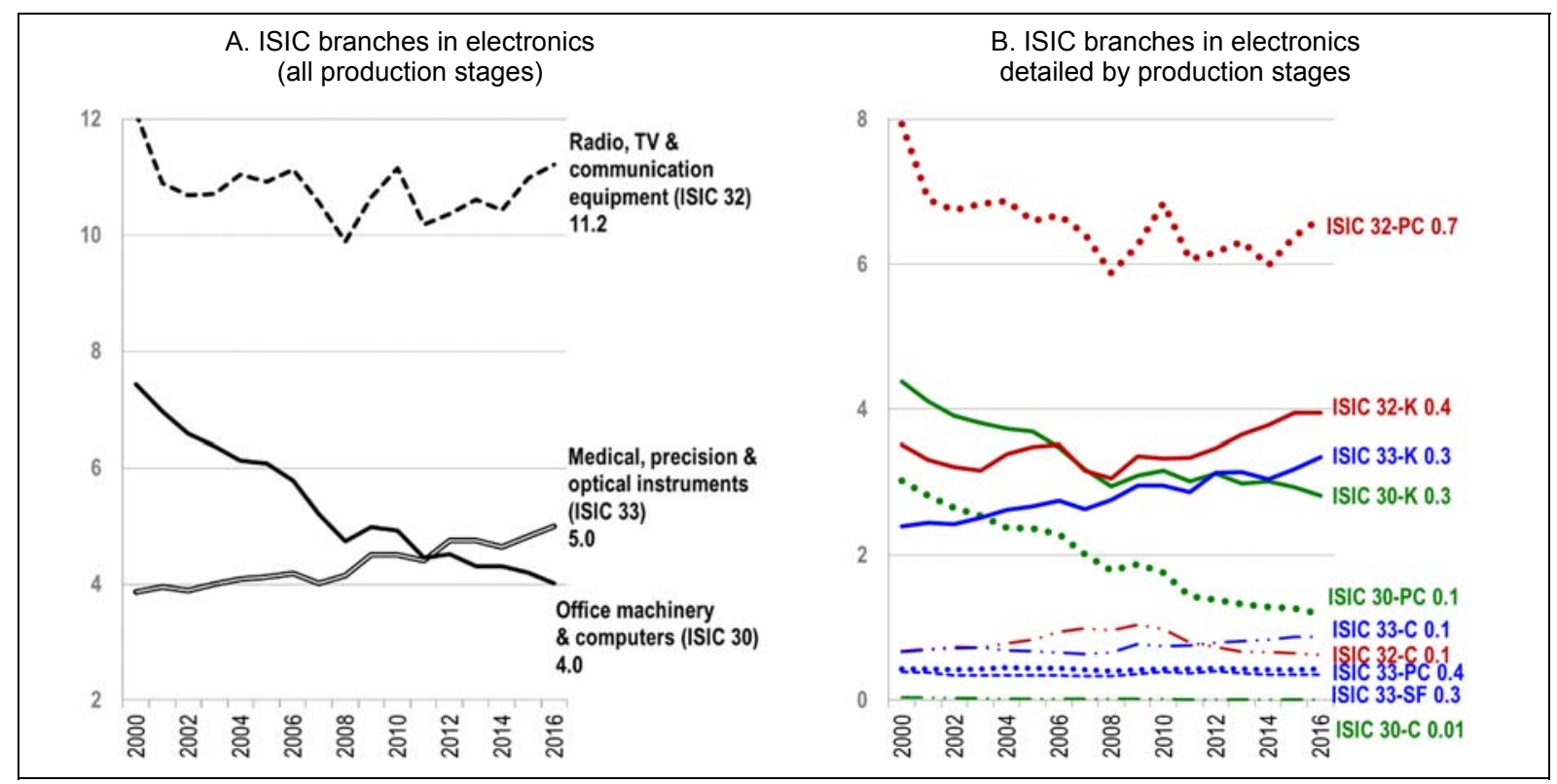

Notes: In panel A HS6 products are regrouped in branches according to 2 digit ISIC classification: ISIC 30 (Office machinery \& computers), 32 (Radio, TV \& communication equipment) and 33 (Medical, precision \& optical instruments). In panel B, these three branches are detailed by production stages: SF, semi-finished goods; PC, P \& C; K, capital goods; and C, consumption goods. Source: Authors' calculations from CEPII's WTFC database. 


\section{Appendix 9 Two supplementary indicators on clients and suppliers diversity}

Figure A.8

Clients and suppliers diversity in world trade: average values by production stages, 2000-2016 (calculated by countries and products at the 6-digit HS level)

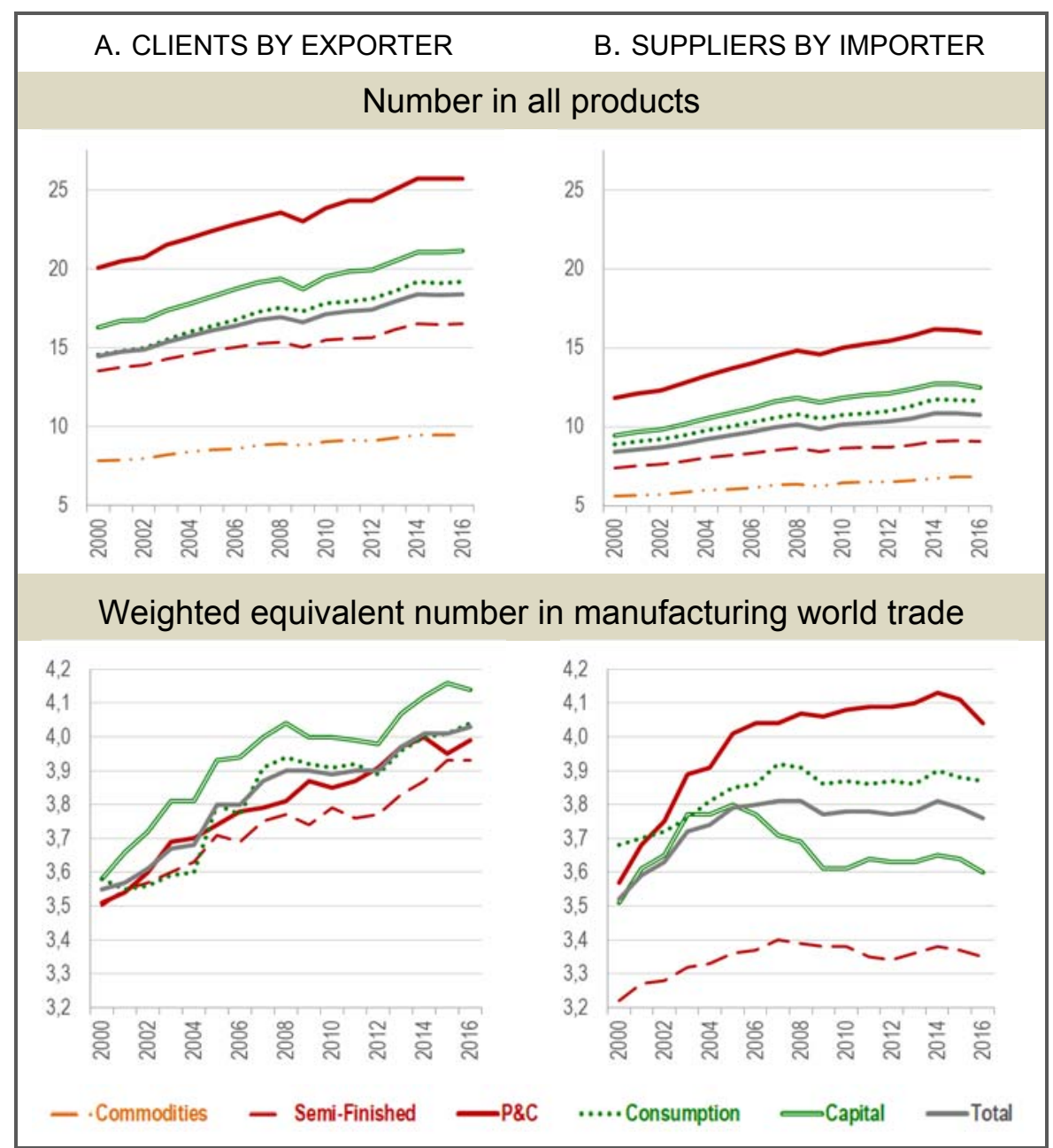

Notes: Weighted equivalent numbers are computed for each country and product at the 6-digit

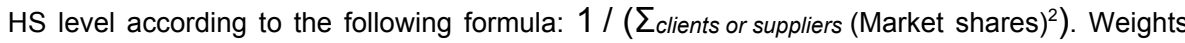
correspond to hs6 trade (average over 2000-2016). Calculations are made only for countries and products available for each year of the 2000-2016 period.

Source : Authors' calculations from CEPII's WTFC database. 


\section{References}

Antràs P. and Chor D. (2013), "Organizing the Global Value Chain", Econometrica, 81(6): 2127-2204.

Aslam A., Boz E., Cerutti E., Poplawski-Ribeiro M. and Topalova P. (2017), "The Slowdown in Global Trade: A Symptom of a Weak Recovery?" IMF Working Paper, 17/242, International Monetary Fund, Washington, DC.

Baldwin R.E. (2016), The great convergence: information technology and the new globalization, Cambridge, Massachusetts : The Belknap Press of Harvard University Press.

Baldwin R.E. and Lopez-Gonzalez J. (2013), "Supply-Chain Trade: A Portrait of Global Patterns and Several Testable Hypotheses”, NBER Working Paper, No. 18957, April.

Berthou A. and Emlinger C. (2011), "The Trade Unit Values database", International Economics, N¹28, Q4, pp. 97-117.

Bloom N., Garicano L., Sadun R. and Van Reenen J. (2009), "The Distinct Effects of Information Technology and Communication Technology on Firm Organization," NBER Working Paper, 14975, National Bureau of Economic Research, May.

Borin A. and Mancini M. (2015), "Follow the value added: bilateral gross export accounting", Banca d'Italia Economic Working Paper, No 1026.

Borin A. and Mancini M. (2017), "Follow the Value Added: Tracking Bilateral Relations in Global Value Chains", MPRA Working Paper, No. 82692.

Boz E., Bussière M. and Marsilli C. (2015), "Recent Slowdown in Global Trade: Cyclical or Structural ?", in The Global Trade Slowdown: A New Normal?, edited by B. Hoekman, VoxEU.org eBook, June, pp. 55-70.

Cingolani I., lapadre L. and Tajoli L. (2018), "International production networks and the world trade structure", International Economics, n¹53, p.11-33.

Crozet M., Emlinger C. and Jean S. (2015), "On the gravity of the trade slowdown", in The Global Trade Slowdown: A New Normal?, edited by B. Hoekman, VoxEU.org eBook, June, pp. 179-196.

Degain C., Meng B. and Wang Z. (2017), "Recent trends in global trade and global value chains", in Global Value Chain Development Report 2017, Measuring and Analyzing the Impact of GVCs on Economic Development, co-published by The World Bank Group, The World Trade Organization (WTO), the Organisation for Economic Co-operation and Development (OECD), the Institute of Development Economics (IDE-JETRO) and the Research Center of Global Value Chains of the University of International Business and Economics (UIBE), Chapter 2, pp. 37-68.

Emlinger C. and S. Piton (2014), "World Trade Flows Characterization: Unit Values, Trade Types and Price Ranges", CEPII Working paper, No. 2014-26, December.

Emlinger C., Guimbard H., de Saint Vaulry A. and Ünal D. (2016), "CEPII Country Profiles: indicators, databases and classifications", Panorama du CEPII, No. ${ }^{\circ} 2016-02$, p. 7, June, http://www.cepii.fr/PDF PUB/panorama/pa2016-02 en.pdf .

Fally T. (2012), "Production staging: measurement and facts", University of Colorado-Boulder, May.

Feenstra R. (1994), "New Product Varieties and the Measurement of International Prices", American Economic Review, 84(1), March, pp. 157-177.

Feenstra R. and Weinstein D. (2017), "Globalization, Competition, and U.S. Welfare", Journal of Political Economy, 125(4), pp.1041-1074. 
Fontagné L. (1991), Biens intermédiaires et Division Internationale du Travail, Economica, Paris.

Fontagné L. and Freudenberg M. (1997), "Intra-Industry Trade: Methodological Issues Reconsidered”, CEPII Working Paper, No. 1997-01.

Fontagné L. and Santoni G. (2018), "GVCs and the Endogenous Geography of RTAs", CEPII Working Paper, N2018-05.

Gaulier G., Santoni G., Taglioni D. and S. Zignago (2015), "The power of the few in determining trade accelerations and slowdowns", in The Global Trade Slowdown: A New Normal?, edited by B. Hoekman, VoxEU.org eBook, June, pp. 93-110.

Gaulier G., Steingress W. and Zignago S. (2016), "Le rôle de la Chine dans le ralentissement des échanges commerciaux", Rue de la Banque, No. ${ }^{\circ} 30$, Septembre.

Gaulier G., Zignago S. (2010), "BACI: International Trade Database at the Product-Level. The 1994-2007 Version”, CEPII Working Paper, No. ${ }^{\circ} 2010-23$, October.

Grossman G. and Rossi-Hansberg E. (2008), "Trading Tasks: A Simple Theory of Offshoring", American Economic Review, vol. 98, No.5, December, pp. 1978-1997.

Haugh, D., Kopoin A., Rusticelli E., Turner D. and Dutu R. (2016), "Cardiac Arrest or Dizzy Spell: Why is World Trade So Weak and What can Policy Do About It?", OECD Economic Policy Papers, No.18, OECD.

Hoekman B. (2015) “The Global Trade Slowdown: A New Normal?”, VoxEU.org eBook, June.

Hofmann C., Osnago A. and Ruta M. (2017), "Horizontal Depth - A New Database on the Content of Preferential Trade Agreements", World Bank Policy Research Working Paper, No. 7981, February.

Hummels D., Ishii J. and Yi K.-M. (2001) "The nature and growth of vertical specialization in world trade", Journal of International Economics, Vol. 54, No. 1, pp.75-96.

IMF (2016) "Global Trade: What's behind the Slowdown?", in World Economic Outlook: Subdued Demand: Symptoms and Remedies, Chapter 2, Washington, October.

IMF (2018), World Economic Outlook: Challenges to Steady Growth, Washington October.

IRC Trade Task Force (2016). "Understanding the weakness in global trade: What is the new normal?", Occasional Paper Series, No. 178, European Central Bank, September.

Johnson R.C. (2017), "Measuring Global Value Chains", NBER Working Paper, No. 24027, November.

Johnson, R.C. and Noguera G. (2017), "A Portrait of Trade in Value Added Over Four Decades", The Review of Economics and Statistics, 99(5): 896-911.

Johnson, R.C. and Noguera G. (2012), "Accounting for Intermediate Production Sharing and Trade in Value Added", Journal of International Economics, 86(2): 224-36.

Laget E., Osnago A., Rocha N. and Ruta M. (2018), "Deep trade agreements and global value chains", Policy Research working paper, No. WPS 8491, Washington, D.C.: World Bank Group.

Lassudrie-Duchêne B. (1985), "L'échange international avec segmentation des produits: une approche par la théorie classique des coûts comparés", in Le Protectionnisme. Croissance, limites, voies alternatives, edited by Lassudrie-Duchêne B. and Reiffers J.L., pp. 737-752, Economica, Paris.

Lemoine F. and Ünal D. (2017), "China's Foreign Trade: A New Normal, China \& World Economy, Vol. 25(2), pp.1-21, April. 
Los B., Timmer M.P. and de Vries G.J. (2015), "How Global Are Global Value Chains? A New Approach to Measure International Fragmentation", Journal of Regional Science, 55(1): 6692.

OECD (2013), Interconnected Economies: Benefiting from Global Value Chains, OECD Publishing, Paris.

Ollivaud P. and Schwellnus C. (2015), "Does the Post-Crisis Weakness of Global Trade Solely Reflect Weak Demand?", OECD Economics Department Working Papers, No. 1216, OECD Publishing, Paris, http://dx.doi.org/10.1787/5js1qvnff3hk-en .

Papageorgiou C. and Spatafora N. (2012), "Economic Diversification in LICs: Stylized Facts and Macroeconomic Implications", IMF Staff Discussion Note, No. 12/13, Washington DC: International Monetary Fund.

Pomfret R. and TSourdin P. (2018), "Value chains in Europe and Asia: Which countries participate?", International Economics, N¹53, pp.34-41.

Redding S.J. and Weinstein D.E. (2017), "Aggregating from Micro to Macro Patterns of Trade", NBER Working Paper, No. 24051, November.

Timmer M.P., Los B., Stehrer R. and de Vries G.J. (2016), "An Anatomy of the Global Trade Slowdown based on the WIOD 2016 Release", GGDC Research Memorandum, 162, University Of Groningen, Groningen Growth And Development Centre.

WTO (2014), World Trade Report. Trade and development: recent trends and the role of the WTO.

Yeats A.J. (1998), “Just How Big is Global Production Sharing?", Policy Research Working Paper, 1871, World Bank, Washington, DC. 